\title{
Las mujeres y el amor en Violetas del Anáhuac. Periódico literario redactado por señoras (1887-1889)
}

\author{
Lucrecia Infante Vargas \\ INSTITUTO MORA
}

\begin{abstract}
Se ofrece una descripción de las diversas imágenes y conceptos que sobre el amor se encuentran en la revista

Violetas del Anáhuac. Se hace hincapié en la importancia de incorporar el estudio de los discursos afectivos en la construcción de la historia de las mujeres, para explicar la complejidad con que se construye culturalmente la diferencia sexual.
\end{abstract}

$\mathrm{E}$ 1 presente artículo quiere ofrecer una descripción general de las diversas formas en que se expresa el sentimiento amoroso femenino en la revista Violetas del Aná huac, elaborada por escritoras de fines del siglo XIX en México; es decir, aproximarse a la manera en que estas mujeres pensaban y probablemente vivieron el amor, cómo se expresaban de él, qué esperaban de sí mismas y "del otro" en la relación amorosa, qué papel desempeñaban en su vida el ideal amoroso y la experiencia de dicho afecto.

¿Por qué atender al discurso amoro- so de estas mujeres? Parto del supuesto de que existe una conexión entre el comportamiento amoroso que las diversas sociedades asignan a las mujeres y la construcción de éstas como sujetos históricos. En otras palabras, parece que la construcción del género ${ }^{1}$ femenino en los diferentes mo-

\footnotetext{
${ }^{1}$ El sentido de la categoría género que aquí se utiliza es el definido del modo siguiente: "El género, como simbolización de la diferencia sexual, se construye culturalmente diferenciado en un conjunto de prácticas, ideas y discursos [...]. Mediante este proceso que es la consti. tución del orden simbólico, en una sociedad se fabrican las ideas de lo que deben ser los hom-
} 
mentos históricos se ha elaborado de manera importante en una relación directa (que no única) con las diversas ideas sobre la naturaleza del sentimiento amoroso en la especie humana. ${ }^{2}$ Lo anterior se enmarca en el reconocimiento de que el ser mujer, es decir la experiencia cultural de lo femenino, se ha determinado general y fundamentalmente con base en la diferencia biológica de los sexos; y que la atribución cualitativa de las diversas "actividades, caracteristicas esenciales, trabajos y formas de vida" 3 asignadas a las mujeres se ha realizado a partir de los diversos conceptos que las explican como tales dentro de un "orden" gobernado por la biología y la filosofia que así lo justifica. ${ }^{4}$ En vista de ello no resulta gratuito que gran parte de las atribuciones y funciones socioculturales que las diversas sociedades han asignado a las mujeres, coincida total o muy cercanamente con la naturaleza y función que la filosofia ha planteado sobre el amor a lo largo de la historia. Además, bajo la conside-

bres y las mujeres". Lamas, "Algunas", 1993, p. 32. Otra definición es: "Para el análisis de cómo se constituye lo femenino, cómo se conforman las relaciones sociales entre los sexos, utilizamos la categoría género para lograr crear una especificidad histórica femenina". Ramos, "Nueva", 1992 , p. 13.

2 "Para quienes buscamos a la mujer en la historia, la cuestión es fundamental porque el género ha sido asociado al amor desde tiempos remotos". Tuñón, "Construcción ", 1990, p. 17.

${ }^{3}$ Lagarde, Cautiverios, 1990, p. 20.

4 "La idea que ha prevalecido, a lo largo de la historia, salvo en el caso de algunos pensadores excepcionales del pasado, y en otros de nuestros días, es la idea de la desigualdad en el ser y en el valer entre el hombre y la mujer". Yamuni, "Ser", 1985, p. 55. ración de que las categorías de subjetividad e identidad están incluidas dentro de los parámetros que constituyen y expresan de manera fundamental la forma en que las sociedades organizan las relaciones sociales entre los sexos, ${ }^{5}$ es evidente la necesidad de incorporar, en la categoría analítica de género, los elementos de lo consciente e inconsciente que conforman las identidades de lo femenino en la condición histórica de las mujeres.

En esta perspectiva, pienso en la vivencia amorosa como un espacio social concreto en el que pueden hallarse elementos que contribuyen a definir, con mayor precisión, el rostro de la nueva perspectiva que sobre la creación de una historia de las mujeres tienen la historia y otras ciencias sociales al adentrarse en la investigación de hechos que hasta ahora no han sido considerados como ejes vitales de la condición genérica. Tal es el caso de la experiencia afectiva. En consecuencia, es necesario atreverse a reconsiderar el uso teórico y el espectro de las categorías analíticas utilizadas, para lograr una visión más amplia de la experiencia humana. ${ }^{6}$

5 Ramos, "Nueva", 1992, pp. 13, 20 y 23.

6 "No reconocer la multiplicidad de posiciones de sujeto y de identidades de las mujeres y los hombres, reduciendo la complejidad de la problemática de las relaciones humanas a una lógica parcial que habla de 'patriarcado' o de la 'opresión de las mujeres' no sólo es reduccionista, sino que conduce al victimismo y al mujerismo que tan frecuentemente tiñen muchos análisis y discursos feministas. Requerimos ampliar nuestra comprensión del destino infausto que compartimos mujeres y hombres como seres humanos incompletos y escindidos, así como de la compleja y amplia gama (con diferencias y 
Debemos señalar que en nuestra contribución a la búsqueda histórica de la experiencia amorosa femenina durante el porfiriato, reconocemos de antemano la complejidad de incursionar en el análisis de los sentimientos y los afectos, incluso dentro de los límites espacio-temporales que la definición implícita de lo histórico contiene. En este sentido y, al igual que otras investigaciones similares, el esfuerzo central de este trabajo se dirige a recuperar y mostrar el testimonio escrito que, en relación con nuestro tema, enuncian las mujeres de una clase social concreta en un momento histórico específico. Creo posible e importante hacer algunas precisiones para conocer cómo fue expresada la idea del amor por estas mujeres y su sociedad y sin pretender afirmar que el concepto del que surge dicho ideal, representa el común denominador dentro de su grupo social particular, el examen de los ideales y de la experiencia del amor expresados en Violetas del Anáhuac, ante la normatividad moral y el imaginario sobre lo femenino imperante en el porfiriato, puede resultar fructífero no sólo para la búsqueda de rastros que nos lleven a concretar el tipo de relación existente entre la práctica real y la prescripción

similitudes) de nuestras desventuras y goces. ¿Para qué sirve la reflexión feminista si no es para leer en términos nuevos el significado de los conflictos ligados a la experiencia humana? Por eso creo que, en vez de usar conceptos totalizantes (patriarcado, opresión de las mujeres) es más útil describir cómo opera la simbolización de la diferencia sexual en las prácticas, discursos y representaciones culturales". Lamas, "Algunas", pp. 51-52. reguladora de la conducta femenina, ${ }^{7}$ sino también a conocer la relación temporal que guardan entre sí los procesos de cambio o permanencia de las diversas estructuras correspondientes a los procesos de cultura. Precisar algunos elementos de la expresividad amorosa reflejada en Violetas del Anáhuac, permitirá responder si el conjunto de ideas que enmarcan dicha concepción y sus prácticas se manifiesta como resultado de la permanencia, supervivencia o cambio (y de qué tipo) de una estructura mental sobre lo amoroso que proviene en gran medida del periodo colonial. ${ }^{8}$

Rescatando las visiones del mundo, mentales y sentimentales, que dan cuenta de la forma particular en que lo femenino se integra a lo social, ${ }^{9}$ y elaborando con ello una historia que reconstruya los diversos cambios y permanencias de lo genérico en los

${ }^{7}$ Lagarde, en relación con la mujer contemporánea, dice: "He analizado la existencia real y simbólica de las mujeres desde una perspectiva antropológica, para encontrar los hitos de su condición genérica (histórica), aquí y ahora en relación a otros tiempos [...], en el camino de la construcción de una teoría histórica que permita aproximaciones a las mujeres reales, plantear problemas y dudas y formular nuevas teorias". Lagarde, Cautiverios, 1990, pp. 17-18.

8 "Es claro que las estructuras mentales se modifican a un ritmo propio que no corre necesariamente parejo con los cambios de indole política y aun social". Tuñón, "Construcción", 1990, p. 182.

9 "La historia puede pretender darie una memoria a la mujer, una imagen de sí misma que la rescate como sujeto historico [...]. Es necesario diversificar las fuentes: atender la novela, las canciones y coplas populares, los diarios personales $[\ldots]$ lo específicamente femenino, su visión del mundo, tanto en mentalidad como en sentimientos". Tuñón, Mujeres, 1987, p. 13. 
diferentes ámbitos de lo humano, nos será posible tal vez hacer de la memoria histórica una herramienta que nos acerque al núcleo de los procesos socioculturales que enmarcan a los "diversos y cambiantes significados de ser mujer a través del tiempo" 10 y que, en consecuencia, nos ayude a reconstruir la historia desde una narración específica de lo vivido: la de las mujeres.

\section{VIOLETAS DEL ANÁHUAC}

La revista Violetas del Anáhuac es una publicación fundamental para el conocimiento del discurso femenino en la segunda mitad del siglo XIX en México. Durante año y medio (de 1887 a 1889) apareció semanalmente los domingos bajo la dirección de la señora Laureana Wright de Kleinhans y, en su última época (febrero-junio de 1889), de la señora Mateana Murguía de Aveleyra. ${ }^{11}$ Sus ejemplares se ven-

${ }^{10}$ Cano, "Remedio", p. 38.

11 Laureana Wright de Kleinhans, directora y fundadora de Violetas del Anáhuac, es una figura central para mirar las estrategias y formas que las mujeres de este periodo elaboraron para incursionar en espacios no tradicionales, como el periodismo. A lo largo de su vida recibió diversas distinciones de parte de clubes y sociedades literarias y científicas por su trabajo como escritora y periodista; ha sido considerada una precursora del feminismo por su interés en rescatar a las mujeres dentro de la historia, así como por plantear perspectivas de oportunidad educacional y laboral no tradicionales para las mujeres de su época. Dicha inquietud se refleja no sólo en los ensayos con que colaboró en la prensa, particularmente para los diarios $\mathrm{El} \mathrm{Fe}$ deralista, Diario del Hogar, El Estudio y, por supuesto, Violetas del Anáhuac, sino también dían por suscripción a 75 centavos mensuales en la ciudad de México y a un peso en las ciudades de provincia; contó con la dirección administrativa del señor Ignacio Pujol. Es necesario mencionar que inicialmente la revista apareció con el título de Las Hijas del Anáhuac, pero cambió su denominación a partir del 29 de enero de 1888 ante la circulación de una hoja suelta, de connotación política, que respondía al mismo nombre. ${ }^{12}$

El contenido regular de la revista lo formaban diversas secciones (todas firmadas por mujeres) que, en general, son una suma de información y ensayos de opinión literaria, doméstica, política, ciencias exactas y naturales, de salud y crónica social, así como biografias de mujeres ilustres. El objetivo esencial de la publicación, como

en sus libros La emancipación de la mujer (1892), Educación errónea de la mujer y me. dio práctico para corregirla (edición póstu$\mathrm{ma}$ ), y Mujeres notables mexicanas (1910). Para mayor información sobre la biografia de Laureana puede consultarse Monges, "Género", 1991, p. 357. Véase también Hernández, "Biografia", 1994.

${ }^{12} \mathrm{El} 22$ de enero de 1888 el periódico anunciaba: "El periódico cambia su nombre por el de Violetas del Anáhuac, con motivo de la aparición de una pequeña hoja suelta con el mismo título, y que perjudica sensiblemente los intereses del presente periódico". Bajo el mismo título de Las Hijas del Anáhuac, apareció una publicación semanal đurante el periodo que va del 19 de octubre de 1873 al 18 de enero de 1874; este semanario estuvo dirigido por Concepción García y Ontiveros y en su elaboración participaban las trabajadoras del Taller de Artes y Oficios para Mujeres. Para un mayor acercamiento a esta revista, véase Tuñón et al., Álbum, 1991. El ejemplar de la publicación está en la sección "Miscelánea" del Fondo Reservado de la Hemeroteca Nacional. 
medio de expresión y divulgación, puede resumirse en lo que expresa la presentación de la revista:

Un medio de expresión femenil, destinado a sostener los intereses, los derechos y las prerrogativas sociales de nuestras compatriotas. La mujer mexicana, adicta por naturaleza a todo lo bello y a todo lo grande, ha llegado en su mayor parte a un grado bastante elevado de ilustración, y necesita por lo mismo un campo donde pueda ensanchar sus conocimientos y darlos a luz, haciéndolos extensivos a su sexo en general, a fin de que se levante a la altura de la sociedad en que vive y de la época que representa. ${ }^{13}$

La diversidad de temas que caracteriza a Violetas del Anáhuac se agrupa en torno a dos formas estilísticas: el ensayo periodístico y la ficción literaria (cuento, poesía, prosa lírica), que a su vez van desde la descripción de los acontecimientos sociales de la burguesía porfiriana y el comentario de lo ocurrido en el país hasta la polémica alrededor de una preocupación básica: la educación de la mujer.

En relación con este último y discutido punto en la prensa de la época, ${ }^{14}$

${ }^{13}$ Las Hijas del Anáhuac, Director y Administrador: señor Ignacio Pujol. Directora Literaria: señora Laureana Wright de Kleinhans, año I, t. I, núm. 1, diciembre 4 de 1887 , México.

${ }_{14} \mathrm{La}$ discusión sobre lo necesario, acertado o no, de brindar a las mujeres la posibilidad de educación superior fue recurrente en diveŕsas publicaciones del periodo. En diarios y semanarios como La Mujer. Semanario de la Escuela de Artesy Oficios; El Álbum de la Mujer. Periódico ilustrado; La Mujer Mexicana. Revista mensual consagrada a la evolución y perfeccionamiento de la mujer mexicana. Dirigida, redac- las autoras elaboraron argumentos con los que intentaron dar razones sobre el beneficio social que representaría el acceso de las mujeres a la educación superior y a áreas de conocimiento diferentes a las tradicionales -religión, moral, cultura, arte general, etc. Las posiciones al respecto oscilan entre una actitud que puede considerarse vanguardista -en la medida en que el derecho de las mujeres a insertarse en áreas intelectuales y laborales no tradicionales se plantea como resultado de una igualdad natural de circunstancias con el varón-y otra tradicional, que plantea la posibilidad de realizar actividades diferentes a la maternidad y el cuidado del hogar como un derecho moral.

Una sección que formó parte del proyecto periodístico de la revista fue la obra literaria. En ese espacio, en que se tratan bajo la misma óptica moralizante temas relativos al mundo familiar de las mujeres ("Hogar", "Mi esposo", "Madre", "Mi fe", "El corazón", etc.), se advierte un rechazo explícito al romanticismo y, al mismo tiempo, una defensa total del naturalismo. ${ }^{15}$ Por último, es importante señalar que,

tada y sostenida sólo por señoras y señoritas; El Correo de las Señoras. Semanario escrito expresamente para el bello sexo; La Moralidad. Peribdico dedicado exclusivamente al mejoramiento de las costumbres y a la extirpación de los vicios. En dichas publicaciones se hallan diversas posiciones al respecto, desde las que descalifican radicalmente la educación profesional de las mujeres hasta las que proponen tal posibilidad como un hecho prudente para las perspectivas futuras del nuevo país que se construye.

15 Para una exposición más amplia sobre el análisis literario en Violetas del Anáhuac, véase Domenella, Voces, 1991, pp. 412.418. 


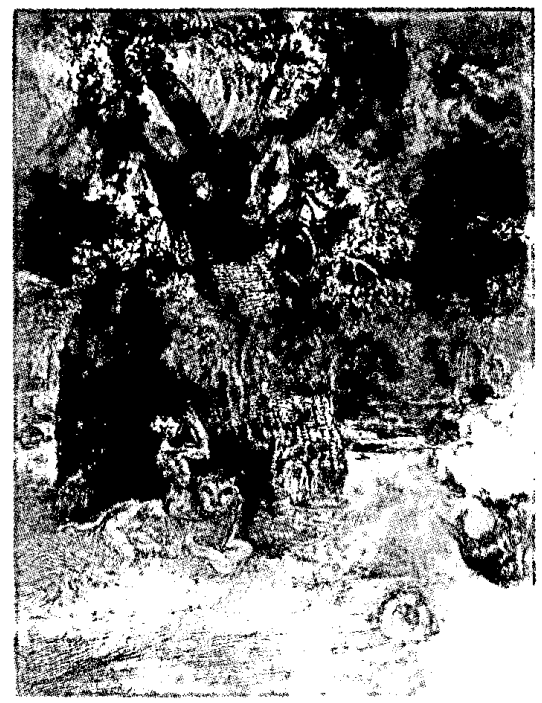

en toda la narrativa, la poesía y la prosa lírica de esta sección, existía un objetivo didáctico en relación con el "deber ser" femenino.

La mujer debe impregnarse en la esencia de sus deberes y posesionarse de su alta misión, no siendo vana, frívola, ligera ni superficial, sino digna y elevada; sin considerarse como la sumisa esclava del hombre, que obedece envilecida los caprichos de su señor, sino como su amiga sincera y fiel compañera [...]. Verdad es que todo espíritu de dominación es intolerante para el sexo fuerte; pero la mujer dominará el corazón de su esposo, sin abrogarse autoridad de ninguna clase ni demostrar altanería, altivez o mal humor; pues la ternura, la dulce persuasión y la condescendencia, son las únicas armas que pueden transformar a un hombre duro, insociable, colérico e indómito, en un ser franco, tratable, amable y bondadoso. ${ }^{16}$

En cuanto a las colaboradoras de la revista, que sumaban casi 30 , varias se dedicaban a la enseñanza, a la literatura o a alguna actividad artística como el canto; pero todas escribían con el interés y la preocupación comunes en el papel que creían deber cumplir en su sociedad. ${ }^{17}$

Es evidente que la mayoría de estas mujeres pertenecía a la clase media formada durante el porfiriato y las etapas inmediatamente anteriores, ${ }^{18}$ y que su educación era excepcional en relación con el analfabetismo imperante en la mayoría de las mexicanas (hacia 1895, sólo existía un $32.35 \%$ de muje.

${ }^{16}$ Elisa (seudónimo), "La mujer", Vtoletas del Anáhuac, año I, t. I, núm. 52, 1888.

17 Existen escasos datos sobre la vida de estas mujeres. Por lo menos sabemos sus nombres: María del Alba, Ignacia Padilla de Piña, Madreselva (seudónimo), Maria de Luz Murguía, Concepción Manresa de Pérez, María del Refugio Argumedo, Dolores Correa Zapata, Titania (seudónimo de Fanny Natali), Anémona (seudónimo), Francisca González, Margarita Kleinhans, Emilia Rimbló, Lugarda Quintero, Elvira Lozano Vargas, Catalina Zapata de Puig, Dolores Puig de León, Josefa Espinoza, Rosa Navarro, Felícitas González, Asunción Melo Río, Ernestina Naville, Antonia Rosales, Carolina Morales, Consuelo Mendoza, María de la Peña, Mercedes Matamoros, Micaela Hernández, Ángela Lozano de Begovich, Blanca Valmont, Mateana Murguía de Aveleyra, Rita Cetina, Mercedes A. de Flores y Dolores Mijares. La obra literaria de algunas de ellas es tratada en Vigil, Poettsas, 1977.

18 Para una caracterización sociocultural y económica de las mujeres pertenecientes a es. tos grupos puede consultarse Parcero, Condtciones, 1992; Lau, "Retablo",1994; Rocha, Ál. bum, 1991 . 
res que sabían leer y escribir en la ciudad de México). ${ }^{19}$ En contrapartida, la revista se dirigía a un sector femenino semejante: mujeres con posibilidad de adquirir la revista y tiempo para leerla. Ello no se contrapone al hecho de que la revista pretendiera ser un órgano informativo para otros sectores de la sociedad, como queda explícito desde el primer número, cuando aún ostentaba su nombre original:

Con el ramo de oliva entre las manos como muestra de la regeneración intelectual de la mujer, vivificadas con las puras enseñanzas de la antigüedad, se presenta hoy al público el modesto periódico Las Hijas del Anáhuac y reverentemente dirige su cordial saludo a todas las clases de su sociedad, a la prensa de todos los matices políticos, y a los hombres de poder y del Estado; trilogía poderosa que, con sus magnificos arneses, ha podido evolucionar victoriosamente en beneficio de la paz, el orden y la cultura de la patria mexicana. ${ }^{20}$

En general, el discurso enunciado en la revista evidenciaba algunos elementos importantes de cómo se entrelazó la influencia de ideas innovadoras sobre la función social femenina y la estructura cultural que determinó a estas mujeres como parte de una mino-

19 Bazant, Historia, 1993, pp. 88-109; González Navarro señala que, para 1890 , en el Distrito Federal había $40.82 \%$ de mujeres que leian y escribían, $4.71 \%$ que leían y $54.47 \%$ que no leían ni escribían; entre 1895 y 1910 había sólo un promedio de $15 \%$ de mujeres alfabetas contra casi $60 \%$ de analfabetas. Véase también González, Historia, 1970.

${ }^{20}$ Las Hijas del Anáhuac, año I, t. I, núm. 1, diciembre 1887. ría social privilegiada. En sus páginas, se reflejan las tensiones y contradicciones internas de la sociedad porfiriana en relación con la instrumentación de políticas y planes económicos que pretendian modernizar al país, contra la permanencia de estructuras de pensamiento tradicionales. Sin embargo, aun frente a la diversidad de actividades y mensajes sobre ese deber ser femenino, resulta evidente la necesidad de construir una nueva imagen en la que lo femenino "conserve las características de sumisión y dependencia que forman parte de la imagen tradicional de la mujer" 21 (imagen fuertemente influida por el espíritu católico, de un lado, y el pensamiento liberal-positivista, del otro), e introduzca nuevos elementos relativos a la imagen de la mujer moderna. Por consiguiente se observa una enorme preocupación por brindar instrucción a las mujeres, aunque dicha inquietud gira, en gran medida, en igual sentido que el que la mayor parte de la prensa de la época establece sobre el debate de para qué educar a la mujer: "Graduar la educación femenina de acuerdo a su condición biológica". ${ }^{22}$ En ese sentido, puede decirse que esas mujeres se veían a sí mismas como parte de una sociedad progresista, a la que deseaban integrarse, sobre todo a partir de una actividad intelectual que ampliara los canales de su desempeño, más allá de su papel como resguardos de los valores morales de la familia y la sociedad en su conjunto. Para lograrlo, tuvieron que elaborar un discurso

21 Ramos, “Señoritas", 1987, p. 160.

22 Rocha, Album, 1991, p. 24. 
que exaltara y revalorara dicha función social y que, al mismo tiempo, diera posibilidades a un nuevo deseo que comenzaba a dibujarse en sus planteamientos: la voluntad de saber y de incidir en su realidad. Ese deseo, sin embargo, habría de dirigirse primero a cuestionar y reinterpretar aspectos de la circunstancia exterior, práctica digamos, en que se expresaba el modelo imperante de mujer. Como veremos, el conjunto de significados ideológicos y culturales que lo sustentaban, en el interior de la estructura subjetiva que conforma la identidad de estas mujeres, hubo de permanecer casi intacto.

\section{EL AMOR EN VIOLETAS DEL ANÁHUAC}

El discurso que sobre el amor y las prácticas amorosas apreciamos en Violetas del Anáhuac, está constituido a partir de un principio básico: la diferencia biológica entre hombres y mujeres, que determina un papel amoroso diferenciado para cada género. Es decir, que el desempeño amoroso y la conducta social atribuida a él se derivan de una diferencia natural. Este principio ordenador de las relaciones sociales a partir de la diferencia biológica tiene sus fundamentos en los postulados de la filosofía positivista, imperante en la ideología social del momento. Ésta, a su vez, establece todo un cuerpo teórico sobre una supuesta naturaleza y función del afecto en las sociedades humanas.

Analizar este discurso de manera pormenorizada resulta complejo, ya que dicho principio dicotómico impregna a la mayor parte de la produc- ción de la revista, por lo que casi siempre parece que el discurso amoroso enunciado es homogéneo, encerrado en los estereotipos del ideal generalizado, si bien he intentado identificar una serie de ideas, espacios y prácticas a través de los cuales se representa la vivencia amorosa, implícita o explícitamente. Así, he clasificado la información de la siguiente manera: 1) la expresión general del ideal amoroso; 2) las formas y espacios concretos en que tiene lugar este amor; 3) la expresión de elementos que parecen proponer un ideal amoroso diferente al dominante, y 4) los conceptos inscritos en el marco de lo prohibitivo, es decir fuera de la normatividad social establecida para la vivencia amorosa. Bajo ese orden intentaré mostrar, en lo posible, qué imágenes del amor y la experiencia amorosa femenina se enuncian, en qué medida ello difiere o se adhiere a la significación del discurso oficial que intenta normativizar la conducta amorosa de las mujeres y qué significa probablemente la excepción o irrupción de un discurso diferente sobre el amor y su práctica. ${ }^{23}$

Es necesario señalar que dicha labor se realiza en función casi única de la fuente revisada y no considera en forma amplia otros posibles conceptos o prácticas testimoniadas en fuentes diversas, como por ejemplo la novela o las canciones de la época, los

${ }^{23}$ Se han tomado también artículos firmados bajo nombres masculinos, no sólo por el supuesto de que pueden ser seudónimos usados por mujeres, sino también porque el ideal amoroso está elaborado siempre a partir de la conducta esperada para uno y otro sexo. 
documentos de corte jurídico, o bien otras revistas y periódicos de la época. Procedemos así no porque no sea indispensable conocer los múltiples rostros del ser mujer y la experiencia amorosa en dicho periodo, sino porque tal labor implicaría extender considerablemente el campo, los elementos y las expectativas de análisis del presente artículo; así pues, este trabajo se plantea como una primera y pequeña incursión en el mundo afectivo de las mujeres del México del porfiriato. $^{24}$

\section{El amor como idea}

El conjunto de textos revisado expresa el amor a partir de dos ideas básicas. La primera explica este sentimiento como un componente esencial de la espiritualidad humana, cuyo fundamento es la misión que se le ha conferido a la mujer para hacer cumplir en la sociedad el orden establecido "de manera natural" por Dios. La segunda lo sitúa como la vivencia a través de la cual se hace evidente la confrontación entre la realización de los designios divinos y la tendencia humana a alejarse de ellos; en otras palabras, el amor se concibe como una especie de oposición constante entre el deber ser amoroso y los hechos concretos, humanos, del amor.

En el primer supuesto, la vivencia

${ }^{24}$ El álbum de la mujer. Antología ilustrada de las mexicanas, resulta un excelente trabajo, entre otros aspectos, de recopilación de diversas fuentes primarias que brindan una imagen amplia y múltiple sobre el ser mujer a lo largo de la historia mexicana. amorosa resulta inseparable de los preceptos religiosos que le dan sentido, colocándola en primera instancia en un ámbito espiritual: " $i$ Bendito sea el amor, símbolo eterno de la vida del alma! Sin amor no habría fe ni esperanza. Sin amor viviríamos sin entusiasmo, sin consuelo, sin alma, sin Dios, que es todo amor". 25 Desde esta caracterización, el amor se plantea como un enlace que "identifica completamente a dos personas y en una sola confunde dos naturalezas" $26 \mathrm{y}$, como dije antes, se considera realmente posible en virtud de la naturaleza divina que se le atribuye:

Mas para que pueda el amor corresponder a su origen divino y perpetuar la especie humana, se necesita que sea espontáneo en su nacimiento, libre en su desarrollo, semejante a las inspiraciones celestiales en su misterios, rápido como la intuición, inefable como la fe, avasallador y tirano sobre la voluntad misma incapacitada de sustraerse a su imperio, superior al libre albedrío y hasta del libre albedrío independiente, algo como la cohesión de las moléculas, la afinidad de los átomos, la gravedad de las esferas, la tracción de los mundos, la luz y el calor de los cielos. ${ }^{27}$

La mujer es considerada un ser de naturaleza afectiva y contemplativa, por lo cual es vista como la intérprete por excelencia del amor, es decir como el instrumento elegido por la divinidad para expresar, cumpliry trans-

25 "Higiene moral", Violetas del Anáhuac, año $\mathrm{I}$, t. I, núm. 24, 1888.

26 "Pensamientos célebres, De Castelar", ibid., año II, t. II, núm. $19,1889$.

27 Ibid. 
mitir el orden terrenal esperado por Dios, ya que se considera que ella

ha sido, es y continuará siendo la clave misteriosa que da solución cumplida y adecuada a todos los grandes y delicados problemas que se relacionan directamente con los destinos del mundo. ${ }^{28}$

Dentro de tal lógica amorosa, hombre y mujer cumplen dos designios contrarios en función de su diferente naturaleza, la cual se advierte como complementaria y como expresión, a la vez, de la forma en que se constituye el orden natural. Así, se piensa que "el hombre y la mujer son dos seres incompletos y relativos, dos mitades de un todo, y por tanto deben amarse $y$ respetarse". 29 Es a partir de esa dicotomía que el poder espiritual conferido a las mujeres tiene como pilares los sentimientos, la moral y la educación, a través de los cuales, se dice, ellas cumplen con su destino material y espiritual: amar, según ejemplifica la siguiente poesía:

Ella que forma del amor su historia y que tan sólo en el amor delira, henchido siente el corazón de gloria cuando escucha los cantos de mi lira, y yo bendigo del amor su historia fuente de inspiración para mi lira. ${ }^{30}$

A partir de esta idea de complementariedad, que define al hombre y a

${ }^{28}$ Emilia Rimblo, "La influencia juvenil", Las Hijas del Anáhuac, año I, t. I, núm. 4, 1887.

${ }^{29} \mathrm{~J}$. Michelet, "La mujer supera al hombre", Violetas del Anáhuac, año I1, t. 11, núm. 21, 1889.

30) Dolores Correa Zapata, "Las dos Liras", ibid., año I, t. 1, núm. 35, 1888. la mujer como dos mitades de un todo, se define un código de comportamiento femenino que debe ser cumplido cabalmente para que las mujeres puedan realizar su función amorosa en la sociedad; papel que, sin embargo, se perfila desde un enfoque masculino de los significados atribuidos a lo femenino:

A la mujer la amamos por ella, por el placer que nos proporciona y nos ha proporcionado; la amamos como obra salida de nuestras manos, esculpida por nosotros y de nosotros impregnada; la amamos por ese sublime atributo del amor que hace que en su abrasadora crisis desaparezca el vértigo y la ofuscación para dar paso a una lucidez perfecta, a su revelación luminosa. ${ }^{31}$

Por ello, existe una serie de recomendaciones sobre los contenidos de la educación que debe brindarse a una mujer, no sólo en la formación moral y espiritual, sino también en relación con su función dentro de los espacios considerados propios de lo femenino, en los que se afirma, por ejemplo, que "lo primero que se debe inculcar a una niña es el amor a la virtud, a la religión y a la fe". ${ }^{32}$ Esta idea del deber ser femenino distingue comportamientos especificos para las mujeres en ámbitos también muy definidos: el matrimonio y la maternidad. Allí, el amor femenino es básicamente el que simboliza su preocupación y ocupación por otros, definiendo a la mujer como

31 J. Michelet, "La esposa quiere asociarse y depender", ibid., año II, t. II, núm. 22, 1889.

32 Elisa, "Instrucción femenil", ibid., año I, t. I, núm. $9,1888$. 
"guardián de la conducta propia y ajena", 33 reiterando la misión "redentora" de las mujeres y exaltando, por último, "la abnegación, el servicio a los demás y la resignación silenciosa ante el dolor, el sufrimiento y los malos tratos", ${ }^{34}$ que son al parecer atributos femeninos dada la misión de la mujer en la vida social; ésta "no sólo es de amor; es también, y acaso más, de abnegación y sacrificio". ${ }^{35}$ Papel dictado siempre desde la mirada del padre, el esposo o el hijo, para quienes la "mujer, esposa y madre, hermana y amiga, ha nacido para la dicha, para la salud de muchos. Dispuesta siempre al sacrificio, no piensa en sí misma con tal de gozar a los demás". 36

Un elemento que no debe pasarse por alto en esta perspectiva de lo amoroso es que, precisamente a partir de la definición que se establece del amor como un acto de la espiritualidad humana, toda su expresión se da con base en elaboraciones idílicas del mismo.

Ángel hermoso que en mi dulce sueño cubres mi frente con tus alas de oro, ideal querido que entusiasta adoro te dirá enamorada el alma mía:

A ti te amo no más, no más a ti. $\mathrm{Y}$ yo feliz con tus caricias puras, al leer tu amor en tu serena frente, te diré en mis suspiros dulcemente: A ti te amo no más, no más a ti. ${ }^{37}$

33 Ramos, "Señoritas",1987, p. 153.

${ }^{34}$ Carner, "Estereotipos", 1987, p. 102.

${ }^{35}$ Laureana Wright de K., "La educación del hogar", Las Hijas del Anáhuac, año I, tomo I, núm. 2, 1887.

${ }^{36}$ Mateana Murguía de Aveleyra, "La Mujer", ibid., año II, t. II, núm. 9, 1889.

37 Dolores Guerrero, "A ti te amo no más, no más a ti", ibid., año I, t. I, núm. 42, 1889.
Por ello la experiencia amorosa establecida entre un hombre y una mujer siempre se presenta como una manifestación básicamente espiritual y se acentúa su oposición con elementos propios de la sexualidad humana, como la excitación corporal producida por los sentidos:

Jamás sintió tu pecho los latidos del ineflable amor que al cielo inclina: la triste realidad de los sentidos no es de ilusión la realidad divina. Amor no es sensación es sentimiento, y el vértigo que pintas no me halaga, ese delirio insano y turbulento, la mente ofusca y el corazón engaña. ${ }^{38}$

En tal perspectiva, queda claro que el amor que el hombre despierta en la mujer está definido como parte de un goce espiritual e inspirado por una emoción otorgada por Dios, donde la intensidad o grandeza de dicho amor se expresa asimismo en imágenes divinizadoras del objeto amoroso hacia el cual la mujer dirige toda su voluntad. En muchas ocasiones esta idea no es tan explícita, pero incluso la ausencia de un discurso específico sobre el cuerpo de los enamorados, como seres sexuados, así como la mención constante de la pasión como un concepto globalizador de cualquier otra relación de pareja que contradice el debido recato - es decir, la ausencia de contacto corporal-es también un dato que refuerza la idea de una experiencia amorosa constituida básicamente por el compromiso entre las obligaciones espirituales y morales, sobre

38 "Amor idealista-Amor naturalista", ibid., año II, t. II, núm. 14, 1889. 
todo-y estrictamente- para las mujeres, a quienes "dar no puede ventura, honor ni calma, el falso amor de la materia impura", ${ }^{39}$ en virtud de que la dicha "es triunfo del amor del alma, amor que Dios bendice, amor que dura". 40

Digo "estrictamente", porque la traducción normativa de la supuesta diferencia entre la naturaleza del hombre y la de la mujer se concreta en la construcción de un estereotipo amoroso masculino relacionado directamente con la acción terrenal humana. En otras palabras, en la medida que se reconoce la incapacidad de la naturaleza masculina para llegar directamente al verdadero amor $\mathrm{o}$ a una espiritualidad desarrollada a través de sus funciones sociales, se acepta como una realidad la relajada conducta de los varones, que se reconoce como no idónea pero tolerable y quizá perfectible:

La mujer no desea otra cosa que pertenecer a su marido por completo y entregarle su voluntad como le ha entregado su corazón. Si el amante se conduce como madre previendo las necesidades de su compañera, viviendo con ella no sólo la vida física sino la vida del espíritu y del pensamiento, la comunión será perfecta, la unión indisoluble, él se habrá apoderado por siempre de la voluntad de la mujer y cuando venga la familia descansará en la sólida base del verdadero amor. ${ }^{41}$

En consecuencia, el concepto acerca de la vivencia afectiva desde lo

\section{Ioid.}

40 Ibid.

41 Mateana Murguía de Aveleyra, "Amor", ibid., año II, t. II, núm. 6, 1889. masculino parece no enjuiciar moralmente la expresión amorosa del propio varón, aun cuando ésta se vincula directamente con emociones producidas por la influencia de los sentidos. $\mathrm{Y}$ al considerar que "un hombre sin corazón es una estatua que parece que piensa", ${ }^{42}$ sus incumplimientos morales en relación con la mujer son siempre socialmente disculpados.

Queda claro también el énfasis por educar a los miembros de uno y otro sexo dentro de un comportamiento amoroso diferenciado, donde la premisa fundamental es la asignación de una naturaleza femenina formada esencialmente por las propiedades y características que se asignan al amor como un elemento de la espiritualidad hu. mana; de ahí que en el caso de la mujer, la ausencia de conductas reconocidas por la normatividad social como emotivas ( $y$, por tanto, naturales) contribuye a desvalorizar sustancialmente el significado atribuido a una mujer, quien "sin corazón es menos todavía: es una estatua que se mueve". ${ }^{43}$

Pasemos ahora al segundo concepto del amor que se expresa de manera generalizada en Violetas del Anáhuac y que, a mi parecer, acentúa la explicación de las contradicciones humanas bajo el supuesto de una naturaleza regida por un orden binario del mundo.

No olvides nunca hija mía, su tierna madre decía, esta sencilla lección: muchas veces lo que amamos

42 "El Corazón", ibid., año I, t. I, núm. 27, 1888.

${ }^{43}$ Ibid. 
al conseguirlo, miramos

deshacerse la ilusión.

Cuando quieras una cosa,

recuerda la mariposa

que viste a tus pies morir;

pues tal vez dejes de amarla

si al pretender alcanzarla,

lo llegas a conseguir. ${ }^{44}$

El amor aparece como un sentimiento de naturaleza contradictoria; elemento importante es que se le considera una experiencia que puede oponerse a la capacidad humana para racionalizar el mundo, es decir para mirarlo y habitar en él a partir de un eje fundamental: la cordura.

Es amor tan rara flor $y$ de tan raro perfume que expuesta al sol se consume $y$ al aire pierde su olor. 45

Se reconoce en el amor una suerte de fuerza avasalladora que somete a prueba la conducta de hombres y mujeres que, no lo olvidemos, han sido educados para adaptar su expresión amorosa dentro de las formas y los espacios permitidos por la moral social, para la cual el enamorado

es un ente lanzado en medio de la creación, como el emblema del movimiento perpetuo; un ente que, ni despierto ni dormido, pasa rápidamente de la rabia de los celos a la ternura del amor, de la ilusión a la realidad, del Paraíso al Infierno. 46

${ }^{44}$ Dolores Mijares, "Las Mariposas", ibid., año I, t. I, núm. 15, 1888.

45 Reinalda, "Un consejo", ibid., año II, t. II, núm. 8, 1889.

46 L.V.B. "El enamorado", ibid., año I, t. I, núm. 12, 1888.
A este conjunto de expresiones emocionales y sensibles no vigiladas por la razón, se les designa como elementos de la pasión. La pasión es vista como ejemplo del amor que desestabiliza al individuo y lo coloca en una situación quizá irreal y dominada por las debilidades de su humana naturaleza. Resulta significativa la asociación que se establece en muchos casos entre el amor y el sufrimiento como un sentimiento inherente a la experiencia amorosa; en tal sentido la imposibilidad de vivir el amor en los términos idealmente prescritos se convierte, en ocasiones, en un incentivo que acrecienta la importancia del sentimiento amoroso incluso en una experiencia infructuosa, y refuerza la definición del amor como un sentimiento de naturaleza contradictoria e inexplicable.

Yo misma no comprendo por qué te quiero tanto

ignoro cuál ha sido la cuna de este amor, que crece con el triste rocío de mi llanto

$y$ vive entre las sombras profundas del dolor.

A solas con tu imagen, mi alma soñadora,

flotando entre las gasas que velan mi se postra de rodillas, $y$ en éxtasis te pasión, adora

dejándote en ofrenda mi pobre corazón. ${ }^{47}$

La constante oposición entre los dictados del corazón del enamorado y los preceptos morales a los que se sa-

${ }^{47}$ Nostalgia (seudónimo), "Meditación", ibid., núm. 37, 1888. 


\section{SECUENCIA}

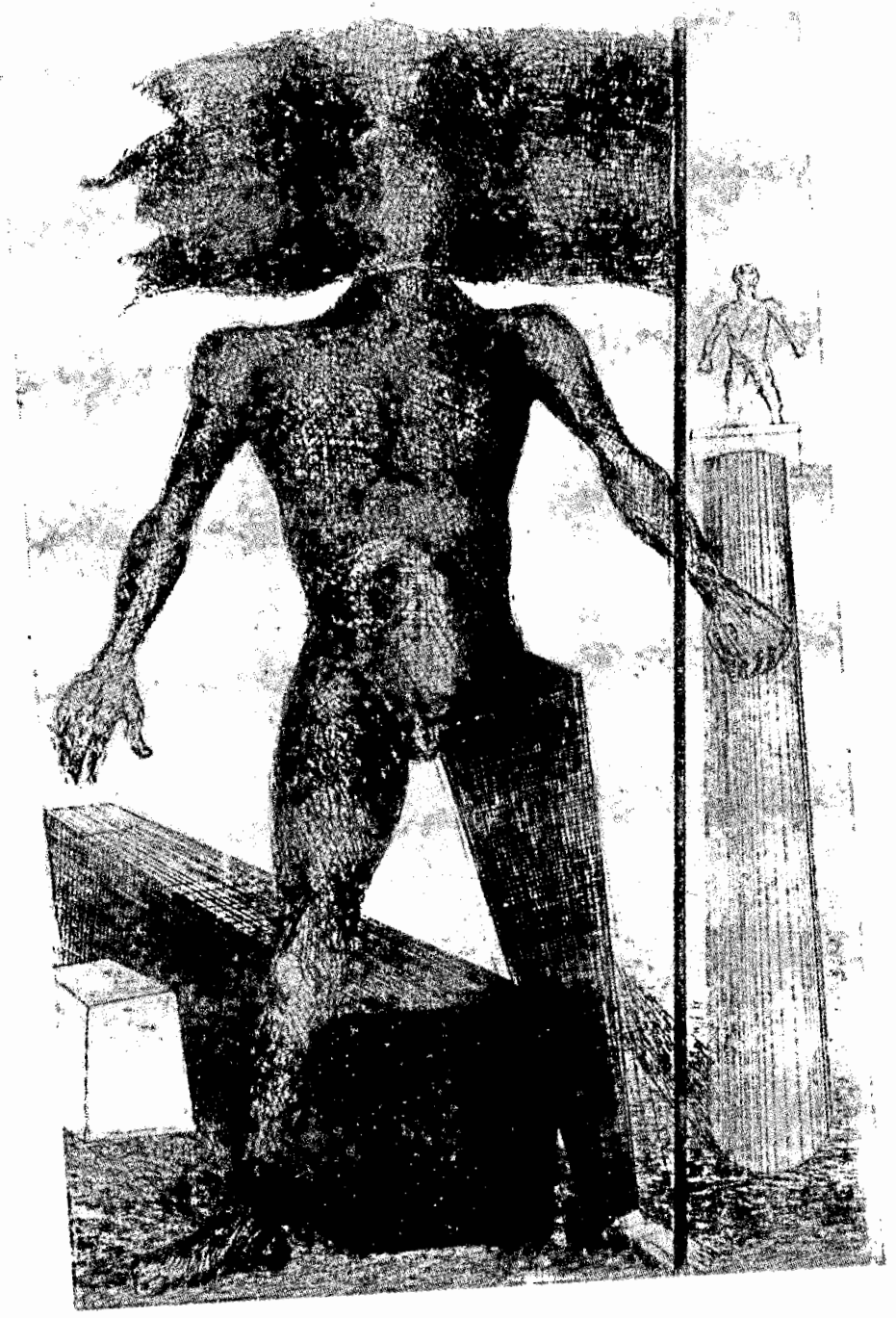


be obligado, se expresa en el entramado social como la batalla perpetua entre el anhelo femenino por contagiar al varón de un compromiso amoroso sustentado en la comunión espiritual-familiar, y la actitud masculina de minimizar la experiencia amorosa dentro de su proyecto general de vida, en vista de que, según se dice, "los hombres suelen tener muy pobre idea del sentimiento de amor, confundiéndolo, iprofanos!, con la mezquina pasión". 48

Dicha situación se traduce también en la continua expresión del sufrimiento femenino ante la falta de empeño y disposición con que los varones asumen su responsabilidad en el desarrollo de la relación amorosa, en virtud de que el amor "no es más que un episodio en la vida del hombre, y la historia entera en la vida de una mujer". 49 Ante esta problemática, el ideal sobre la naturaleza de lo femenino se convierte una vez más en el catalizador que resuelve la inmutabilidad de las diferencias entre hombres y mujeres para asumir sus deberes sociales. Así, frente a los conflictos amorosos ocurridos como consecuencia de las diferentes disposiciones e intereses para el amor entre ambos géneros, la capacidad femenina de sobrellevar toda situación adversa (en términos de abnegación y resignación) se exalta de nuevo como un instrumento dado naturalmente a las mujeres para cumplir su papel social.

48 Rosa Navarro, "Romances dedicados a la Señorita Ma. del Alba", ibid., año II, t. II, núm. 4, 1889.

49 "Pensamientos Célebres, Mad.Stael", ibid., núm. 17, 1889.
Muchos hombres no pagan ni agradecen el amor de las mujeres, pero las mujeres pagan siempre el amor de los hombres, no digo que no haya excepciones... ¡Benditas sean las mujeres que prodigan su amor por más que casi siempre sea su premio la ingratitud! Y es que como decía Shakespeare: el amor se gasta más pronto en la imaginación de los hombres que en la de las mujeres. ${ }^{50}$

También hallamos un extenso cuerpo de consejos que se recomienda asumir a las mujeres que enfrentan adversidades en su experiencia amorosa; así, desde la precaución señalada para seleccionar novio o marido ("fijaros caras amigas, para conyugal unión, en hombre recto y juicioso que opine que el santo amor, es el lazo de las almas prendido del corazón" $)^{51}$ hasta el sinsabor provocado por una relación amorosa no correspondida -el engaño o la traición del amado-deben ser asumidos por la mujer dentro de los preceptos morales que su pretendida naturaleza y la normatividad social le asignan; ya que dichas situaciones son consideradas como sucesos que toda mujer deberá enfrentar (en virtud de las debilidades naturales de su compañero) y sufrir resignadamente, confiando en que "el placer tiene su fascinación; pero ésta, desaparece cuando se alcanza, dejando así siempre hastío en el corazón, vergüenza en el rostro y tortura en los recuerdos"; 52 y en que, de cualquier manera,

${ }^{50}$ C.F., "La novia", ibid., año I, t. I, núm. 10 , 1888.

51 Rosa Navarro, "Romances dedicados a la Señorita Ma. del Alba", ibid.

52 B.M., "La mujer celosa", ibtd., año I, t. I, núm. 25, 1888. 
la sociedad lo castigará con su desprecio, y su conciencia con el remordimiento, y de que algún día caerá de sus ojos la horrible venda de sus caprichos, para que vea convertido en cenizas el ídolo de sus placeres y en perpetua irradiación de luz la aureola de su compañera si es virtuosa. ${ }^{53}$

Para el caso de los celos, es también el apego a la cordura de esta naturaleza tolerante lo que debe regir, según se recomienda, pues las pasiones de una mujer celosa la hacen "terrible, amenazante y hasta fiera en sus instintos", ${ }^{54}$ y alejada de la forma socialmente aceptada para expresar este sentimiento:

Convenimos en que una mujer sea celosa, pero celosa digna del celo que siente; que no se rebaje por él ni se exponga a perder la felicidad de su hogary de sus hijos y hasta su honor, como sucede muchas veces. 55

Ello en función del constante recordatorio sobre que "las obras de la mujer son de sentimiento y sus actos no deben respirar sino tolerancia y abnegación", pues "no hay hombre, por embriagado que esté en los culpables atractivos de criminales afectos, que no sienta en su alma la herida del remordimiento, cuando su esposa es buena". 56

Esta resignación ante el sufrimiento suele expresarse también comola ausencia de alternativas para resolver la con-

53 Ibid.

${ }^{54}$ Ibid.

55 Ibid.

56 Ibid. tradicción ante otra situación ya mencionada, el amor no correspondido:

Aunque sepa que nunca me has querido, aunque sepa que nunca me querrás, yo te quiero decir que no te olvido, que me siento morir donde no estás. Y aunque el delirio de mi mente extrañes,

necesita mi pobre corazón que vuelvas, que me mires, que me engañes, que finjas que me adoras con pasión. Dime que mienten los que me ha contado que eres dichoso sin pensar en mí; ¿Ven, porque está mi corazón cansado de hablarte en vano, de llorar por ti! ${ }^{57}$

Finalmente, es muy importante anotar el constante recurso de la divinidad como la única entidad capaz de enjuiciar y aplicar sanción algưna a la conducta masculina en relación con su comportamiento amoroso (en términos básicamente espirituales), frente a la aparente aceptación general de que, la realidad amorosa vivida por las mujeres, pueda no brindarles casi nunca una realización total de sus aspiraciones si se piensa que "el amor es un niño grande, la mujer es su juguete"; 58 cirounstancia ante la cual cabe el consuelo de confiar en que

si no el amor, porque el amor es independiente de la voluntad, ciertos sacrificios de amor propio, ciertas manifestaciones de nobleza y ternura de

57 Nostalgia (pseudónimo), "Invocación", ibid., núm. 17, 1888.

58 "Pensamientos célebres, N.N.", ibid., año II, t. II, núm. 17, 1889. 
sentimientos, conquistan cariño eterno e inmutable. 59

\section{Las edades del amor}

La experiencia amorosa de las mujeres recorre ámbitos específicos mediante un ritmo evolutivo que se asocia al ciclo de la vida: noviazgo, matrimonio, maternidad. Son los intervalos espacio-temporales en los que, según se piensa, las mujeres ejercen ampliamente la misión espiritual de su naturaleza y cumplen las tareas fundamentales que les son asignadas socialmente como ejes y administradoras del círculo doméstico y como educadoras de los hijos.

El noviazgo es considerado el primer nivel o la puerta de entrada permisible a la experiencia amorosa entre un hombre y una mujer. Se habla de esta relación como la etapa "feliz" o de mayores alegrías para la futura esposa que, en su calidad de novia, "recorre, desde que puede llamarse así, un camino lleno de flores y en el que encuentra mil ocasiones de halagar su vanidad de mujer"; ${ }^{60}$ y parece adquirir un rango o casi diríamos una esencia ontológica al establecer dicha relación con un varón cuando, por ejemplo, se estipula rotundamente que "el significado etimológico de la palabra 'novia': es la mujer que estaba ciega cuando aún no era novia de alguien". ${ }^{61}$

59 M. del P. S., "Consejos de Mujer (a una casada)", ibtd., núm. 5, 1889. 1888.

$6^{\circ}$ C. F., "La novia", tbid., año I, t. I, núm. 10 ,

61 Ibid.
Debido a que el matrimonio se piensa como la forma de relación que sucede al desarrollo de un noviazgo establecido dentro de los cánones dictados por la moral social, el compromiso de boda preasignado al noviazgo se asemeja a una especie de iniciación en el aprendizaje de una experiencia que, socialmente, se designa como fundamental en la vida de una mujer: su matrimonio. De tal suerte, se considera que las mujeres "no tienen más carrera que el matrimonio", razón que justifica su preocupación por "disputar los prospectos de novio"; 62 el noviazgo indica así una importancia tal que se piensa debería existir una "escuela para novias", pues

aunque parezca una utopía [...] tanto el cuerpo como la inteligencia y el espíritu de la mujer deben estar educados y preparados para el solemne día. Así la mujer no sería una cosa que se entrega sino una persona a quien se consulta. 63

Existe también todo un código de comportamiento a seguir por los novios, tanto en la manera de establecer el noviazgo como durante el mismo. Este código se desarrolla a partir de diversos símbolos que traducen el grado de interés mutuo y la disposición a establecer una relación formal. En esta suerte de reglamentación conductual, la actitud femenina es siempre indirecta y determinada por las formas de comportamiento establecidas moralmente como propias de una "señorita decente". Un modelo antitético de este

62 Ibtd.

63 Mateana Murguía de Aveleyra, "Amor", ibid., año II, t. II, núm. 6, 1889. 
comportamiento es señalado de la siguiente forma:

Esta falsa y decantada ilustración, es la que proporciona a la mujer un amor propio sin límites, un orgullo insoportable, una extremada fatuidad y una odiosa altivez. Ésta es la llamada instrucción que posee una multitud de frívolas jovencitas, austeras en su moral y voluptuosas en su conducta, se sonrojan de saludar en presencia de otros a algunas de sus amigas, cuya fortuna no es igual a la suya. Sin piedad, sin religión, sin moralidad, sin plan y sin principios concluyen por causar la desgracia de su esposo, si algún desgraciado cautivado por su hermosura física les ofrece su corazón y su mano. ${ }^{64}$

El matrimonio es la forma por excelencia en que debe cumplirse o consumarse el amor de una pareja; se le considera el estado ideal para lograr que el hombre y la mujer respondan a sus respectivas misiones espirituales y sociales. Esta relación se define siempre en términos de una institución básicamente espiritual y moral, en la que el amor de los esposos es calificado como adecuado con base en los preceptos religiosos, y establece entre ambos una unión que se considera eterna o al menos perpetua. Al respecto, es significativo que el contrato civil de matrimonio no se mencione nunca; en cambio, se insiste siempre en la importancia de realizar la unión matrimonial a la sombra de los preceptos de la Iglesia católica. ${ }^{65}$ De hecho, "entregar" el amor

64 Elisa (seudónimo), "Instrucción femenil", ibid., año I, t. I, núm. 9, 1888.

65 No debe olvidarse que el establecimiento legal del matrimonio civil era un hecho reciente fuera de los ritos eclesiásticos es considerado un grave pecado y casi siempre se asocia con un destino infortunado. El matrimonio es considerado también el fin último en la vida de una mujer, es un evento que la coloca en el mejor de los planos para llevar a cabo su proyecto vital en la sociedad.

¡Oh, tú no sabes lo que el alma errante siente al llegar al árbol do se posa, cuando se cambia el título de amante por el más dulce título de esposa. La sangre corre en rápidos vaivenes. Quiere saltarse el corazón al pecho. La corona nupcial en nuestras sienes, nos trae la esclavitud... ¡ huye el derecho! Mas, ;oh bendita esclavitud que adoro!, en que se reina al par que se obedece. Cadenas tiene mas cadenas de oro... Déjame en mi entusiasmo que las bese. ¿Por prisión el hogar!, prisión que imita al mismo cielo y que la ley bendijo. ${ }^{66}$

En esta bendecida prisión matrimonial, la mujer representa una especie de muro de contención entre el ámbito privado de la familia y los elementos del exterior o públicos, en tanto "repara todos los días el corazón [de su esposo] por medio de la música de la noche", ${ }^{67}$ siempre desde el espacio privado que se le concede como idealmente propio a la mujer y a lo femenino en virtud de su condición espiritual.

en relación con el tiempo real con que cambian las costumbres y estructuras mentales, lo que no se produce nunca de forma automática o en correspondencia paralela a la implantación de medidas de este tipo.

${ }^{66}$ Mercedes A. de Flores, "Amor", Violetas del Anáhuac, año II, t. II, núm. 17, 1889.

${ }^{67} \mathrm{~J}$. Michelet, "De la fe común", ibid., núm. $19,1889$. 
Ella es el ángel del hogar, miradla allá en el fondo de su humilde alcoba entre su amor y sus faenas pasa de su existencia las tranquilas horas. Alli del ruido mundanal no turba la algazara constante y fatigosa ni se escucha del alma acongojada el iay! doliente que derrama a solas. ${ }^{68}$

La idea de la mujer como una sacerdotisa o una regeneradora de los vicios humanos es constante en el discurso amoroso; ${ }^{69}$ así como la asignación de los espacios y deberes que pertenecen a cada sexo. Es por ello que la mujer debe "impregnarse en la esencia de sus deberes y posesionarse de su alta misión" y, en relación con su marido, "debe evitarle caer en el precipicio del error o del vicio por medio de la dulzura, el talento y la abnegación". 70

Para ello existe una amplia gama de recomendaciones sobre la conducta que debe seguir una esposa en su esfuerzo por establecer un "buen matrimonio" o en última instancia, para sobrellevarlo dignamente. Es decir que, de acuerdo con la apreciación

68 "El ángel del hogar", ibid., año I, t. I, núm. $42,1888$.

${ }^{69}$ En relación con esta imagen, resulta interesante el siguiente fragmento: "Genio del bien y del mal, ángel tutelar de los hogares, o espíritu maligno que enciende las más enconadas discordias, sacerdotisa que consagra y depura los holocaustos, falsa y pérfida sibila que al hombre comunica e inspira los delirios más fascinadores que brotan de su númen prolífico: Magdalena, en un palabra, a quien acaso casi siempre puedan perdonárscle los males que ocasiona, porque AMO MUCHO...". Emilia Rimbló, "La influencia femenil", Las hijas del Anáhuac, año I, t. I, núm. $4,1887$.

70 Elisa, "La mujer", Violetas del Anáhuac, aก̃o I, t. I, núm. 52, 1888. moral de su función natural en la sociedad, por la cual -según se llega a decir- "la mujer es, en cierto modo, responsable de la conducta del marido" y debe, por tanto, "presentarse a sus ojos con igual encanto y los atractivos que cuando lo cautivó, hasta el punto de renunciar por ella a su libertad de soltero y a sus placeres de joven"; por ello se considera que la esposa debe preocuparse por "mantener el sagrado fuego del hogar, prolongando indefinidamente la ilusión, distribuir el tiempo entre lo que representa el lado material de la vida y lo que pertenece al orden moral, tener siempre encendida la llama de la inteligencia", todo ello con el propósito de que "no la halle el esposo desprevenida como a las 'vírgenes necias' de la Biblia". ${ }^{71}$

En síntesis, la naturaleza asignada a lo femenino y las ocupaciones que se supone derivan de ella, establecen un amplio grado de flexibilidad en relación con las formas y medios a través de los cuales las mujeres puedan cumplir con la función de mantener el estereotipo de relación hombre-mujer recomendado socialmente, en el que ellas adecuen siempre sus propias expectativas, sentimientos e ideas con base en la conducta masculina:

A las mujeres, que tienen el oúdo más fino y por regla general pueden disponer de más tiempo, les ruego presten atención a lo que voy a decirles; $\mathrm{cl}$ hombre, ese mártir del trabajo, en medio del vértigo del esfuerzo, aturdido, no me oiría. Señora, no sea Ud. perfecta; conserve un defectillo suficiente para con-

71 María de la Peña, "La mujer en el hogar", ibid., núm.. 51, 1888 


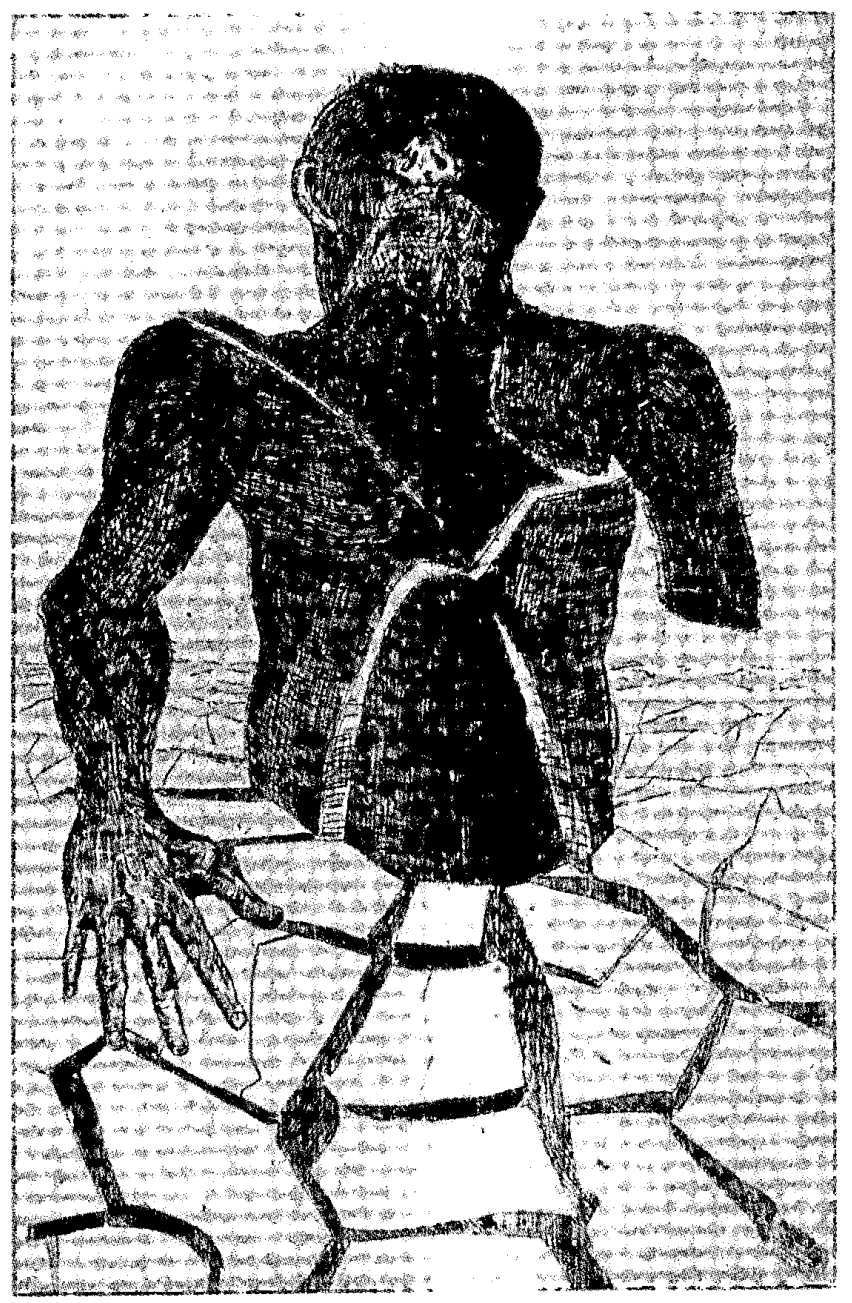


solar al hombre. La naturaleza quiere que éste sea soberbio, y siendo así, como lo es, en interés de Ud. y en el de su familia está el que lo sea y se crea fuerte. Cuando lo vea Ud. abatido, triste y desalentado, puede decirse que el remedio estriba en que Ud. se humille, en que sea más mujer, más joven, niña si a mano viene. Otro consejo: no comparta Ud. el corazón con nadie más que con su marido. ${ }^{72}$

La maternidad, como función de la mujer, es la otra parte del binomio matrimonio/familia o maternidad/matrimonio. Actividades y espacios que se conciben y explican siempre de manera conjunta. Ambas son expresiones características de la sublimación amorosa a que se supone llegan las mujeres por su naturaleza, ya que

el instinto de la maternidad y el amor a la familia que se manifiesta en ella desde los primeros años de su infancia hace que, en largos diálogos con su muñeca..., repita las lecciones de moral y urbanidad que recibe de sus padres. ${ }^{73}$

El estereotipo de la madre educadora y hogareña es uno de los ideales fundamentales en la ideología propuesta y difundida por los grupos dominan. tes del periodo. ${ }^{74}$ Considerada prácticamente como instinto básico en la mujer, la maternidad la define como sujeto en virtud de su capacidad bioló-

72 J. Michelet, "La mujer supera al hombre", ibid., año II, t. II, núm. 21, 1889.

${ }^{73}$ Mateana Murguía de Aveleyra, "I a mujer", ibid.,núm.9, 1889.

${ }^{74}$ Françoise Carner señala que "existen diversas imágenes de mujer según la clase a que pertenecen". Véase "Estereotipos", 1987, p. 106. gica para reproducir la especie. Alrededor de la maternidad se sitúan un sinfin de "beneficios, virtudes y conveniencias" 75 a través de las cuales las mujeres cumplen con su destino positivo (entiéndase normal o natural de acuerdo con la filosofia del mismo nombre que tuvo gran influencia en este periodo). Se dice, por ejemplo, que si "al abandonar su familia y casarse, valerosa y confiada se entrega a un dueño que quizá sea altivo y duro", ello no importará si "éste le da la suprema dicha de ser madre" y, de esa forma, "al transformaria física y moralmente" él llegará a ser "su dios sobre la tierra, su amor único, su religión", ${ }^{76}$ pues "el amor abnegado y sublime de la madre es la esencia más delicada del amor y el sentimiento", y puesto que "una madre es feliz en su hogar, junto a la cuna de su hijo, meciéndolo suavemente y contemplando su dulce sueño", a una mujer no le importará "el ruido, el esplendor bullicioso de la sociedad, si sus hijos la encantan con sus sonrisas". ${ }^{77}$

La maternidad como destino femenino se asocia también al supuesto de que la capacidad amorosa-materna de las mujeres expresa la naturaleza divina del sentimiento amoroso, cuya función social es -como ya dijimosel mantenimiento del orden y la estabilidad del mundo afectivo. Así, la figura de la "gran madre", como expresión por excelencia de la supuesta natura-

75 Ramos, "Señoritas", 1987, p. 149.

76 Mateana Murguía de Aveleyra, "Ia mujer", Violetas del Anáhuac, año n, t. II, núm. 9, 1889.

$77 \mathrm{Ma}$. del Refugio Argumedo, "Amor maternal", ibid., año $\mathrm{l}, \mathrm{t}$. $\mathrm{l}$, núm. 10, 1888. 
leza afectiva femenina, engloba también, según me parece, el concepto sobre la función social del amor y su expresión en el mundo a través de las mujeres, quienes deberán convertirse en el conjunto imaginario de lo femenino considerado esencial en la vida de un hombre, brindádole tanto "el santo afecto de su madre muerta ya" como el "hechizo de su amante ya olvidada" ${ }^{78}$ Estas varias funciones afectivas establecen sin embargo una posibilidad univoca para experimentar la felicidad: una felicidad en la cual la mujer debe olvidarse de sí misma para cuidar, vigilar y procurar lo necesario para la vida de sus hijos y de su cónyuge, y así como el matrimonio es la expresión del camino adecuado para que las mujeres encuentren el marco ideal de realización personal, el cumplimiento de la maternidad se muestra también como el evento que complementa su ser y que llena el vacío de una primera identidad afirmativa desde su calidad inmediata de ser humano. Se dice, por ejemplo, que "cuando una mujer no ha tenido hijos no es feliz" porque más allá de la posible experimentación del amor dentro del matrimonio, "el amor de los amores no ha inundado de dicha su corazón y todos los demás afectos le parecen tibios y descoloridos". ${ }^{79}$ En síntesis, el sentido total de la felicidad para una mujer está determinado por la posiblidad o no de "ver crecer a sus hijos", lo cual se considera "la mayor dicha y gloria para

\footnotetext{
${ }^{78}$ María de la Peña, "La mujer en el hogar", ibid., núm. 51, 1888.

${ }_{79} \mathrm{Ma}$. del Pilar S., "Consejos de mujer (a una casada)", ibid., año II, t. II, núm. 5, 1889.
}

una mujer", quien, ante la experiencia de este evento biológico, "no debe pedir al cielo ninguna otra, porque ya ha alcanzado su parte de felicidad en la tierra" 80

\section{Un ideal amoroso diferente}

Ahora queremos resaltar la presencia de breves y esporádicos discursos sobre el amor que, de forma superficial o profunda, cuestionan el ideal amoroso imperante e introducen elementos que forman ya un concepto diferente del tradicional, sibien no rompen del todo con la estructura básica im. puesta socialmente. Me ha parecido importante esta distinción por la posibilidad que brinda para evidenciar cómo, aun dentro del limitado espectro que representa el análisis de lo amoroso a partir de una sola publicación de la época (determinada además por la visión de clase a que pertenecen sus autoras), es posible observar que la recreación del ideal establecido y el tránsito hacia la elaboración de nuevos ideales son procesos que interactúan entre sí. En otras palabras, podemos ver cómo se establecen los cambios en confrontación con las continuidades del ideal amoroso predominante.

En primer lugar, hallamos un claro cuestionamiento sobre las responsabilidades establecidas para hombres y mujeres en la relación amorosa, ya que en virtud de la inequidad con que éstas han sido asignadas, las

ipobres esposas! ni siquiera tienen trazada la actitud que deben tomar cuando

${ }^{80}$ Ibid. 
las engañan, pues si se alteran las tratan de no ser señoras, y si permanecen impasibles dicen que es porque no aman a sus maridos. ${ }^{81}$

En este sentido, parece oportuno reconsiderar dicha situación, pues "hasta hoy, los autores de todas las épocas se han ocupado siempre de trazar a la mujer sus deberes conyugales, con el fin de enseñarle el arte de conservar la paz doméstica"; y pese a que la intención de dichas preocupaciones mas. culinas es considerada importante porque aconseja "un comportamiento capaz de llevarla a obtener el mayor de todos los bienes: la tranquilidad de su hogar", se plantea que el conjunto de indicaciones señaladas para que logre "ser prudente, aseada, ecónomica, tierna y delicada", para que pueda "estudiar atentamente el carácter y costumbres del compañero de toda su vida" y "amoldar convenientemente las suyas", así como la recomendación de que "debe reprimirse en todo para evitar que su esposo se disguste de verla melancólica, enferma o violenta; y aún que posea para halagar no sólo el sentimiento, sino hasta la vanidad de su dueño", resultan planteamientos que, como se dice, acentúan "la idea de que ella sola es responsable de la felicidad o desgracia de su hogar", 82 cuando, en realidad, "no sólo la mujer ha de poner los medios, sino que el hombre también debe sacrificar algo

81 "También los suegros", ibia, año I, t. I, núm. 34, 1888.

82 Mateana Murguía de Aveleyra, "Los maridos", Las Hijas del Anáhuac, año t, t. I, núm. 4, 1887. de sus ideas, de sus costumbres y de sus gustos". 83

Dicho planteamiento adquiere el tono de reclamo ante tal estado de cosas y propone comoaltemativa "edu. car a los hombres para el Amor", en vista de que "el hombre inculto o ignorante en el verdadero amor, no ve en él más que un medio para hacer la guerra a la mujer, abusando de su miseria para marchitarla, envileciéndola y [...] hundirla otra vez en su primitiva miseria y abandonarla a su desesperaciốn", a lo que se agrega el que a "la débil mujer no la apoyan ni la sociedad, ni la Iglesia, ni las leyes, ni la familia". ${ }^{84}$

Esta especie de reeducación es pen. sada para ambos sexos, pues no sólo a los hombres "se les ha hecho creer que ellos al casarse sólo van a mandar", o bien a "ejercer su despótica autoridad y satisfacer todos sus caprichos, sin preocuparse siquiera de si esto es a costa de la tranquilidad y aún de la salud de su esposa"; sino que tam. bién las mujeres "están poco instruidas en su deberes conyugales", por lo que "las pobres mujeres de tales mari-" dos viven siempre sobresaltadas, inquietas y temerosas de que hasta la más inocente de sus acciones pueda disgustar al señor" 85

El sentido esencial de esta propuesta reeducadora se dirige a revalorar el estatuto moral de las mujeres en la sociedad y, por tanto, en la vida familiar y matrimonial. En este intento se acen-

83 Ibid.

84 Mateana Murguía de Aveleyra, "Amor", Violetas del Anáhuac, año II, t. I, núm. 6, 1889.

85 Ibid., "Los maridos", ibid., año $\mathrm{I}, \mathrm{t}, \mathrm{l}$, núm. 4,1887 . 
túa la importancia social de ampliar los horizontes de la educación y la ocupación productiva de las mujeres, ya que "la mujer influye en todas las edades de su vida, en todos los acontecimientos; desde los más trascendentales, hasta los más insignificantes hechos de la vida doméstica y social"; y por tanto, la mujer se percatará a través de una nueva educación de que "no es un espíritu inferior a quien Dios plugo arrojar a este mundo sólo para que sufriera", y confirmará también "que su alma es igual a la del hombre, que tiene las mismas facultades y derechos que éste para trabajar en su progreso intelectual y moral". 86

Como puede observarse, esta expresión amorosa que busca la posibilidad de una responsabilidad moral igualitaria entre ambos sexos, no pretende por ello trastocar la relación estructural esencialista que determina finalmente las características atribuidas a lo femenino y a lo masculino, ya que continúa reconociendo a la mujer como el sujeto depositario, por naturale$\mathrm{za}$, de aspectos humanos considerados loables que son relacionados directamente con la expresión afectiva y sentimental. No obstante, dicho replantamiento pone en claro el sentido que durante el periodo de nuestro estudio distingue los nuevos conceptos sobre lo femenino y que, en algunos análisis, han sido identificados como un naciente feminismo. En relación con ello, me parece que, en efecto, contemplamos el surgimiento de un discurso que gira en torno a la necesidad de afirmar

86 Micaela Hernández, "Educación de la mujer", ibid., año II, t. II, núm. 24, 1889. un sentido de autoestima femenina, elemento de suma importancia si consideramos el contexto histórico y asimismo la fuerza de la correspondiente ideología dominante, donde las expectativas de vida de las mujeres se definían en relación exclusiva con el cumplimiento de su desempeño como madre, esposa o hija, y no por el desarrollo de actividades destinadas a una satisfacción o beneficio personales.

Serán menos las que ignoren lo que valen, lo que pueden y deben hacer. Y por último serán menos las que desaparecen en el olvido sin dejar una huella de su existencia. Cuando ella se levante, se contemple y se sienta con derechos y voluntad para remontar su pensamiento al infinito, entonces será una realidad su emancipación. Si el hombre no quiere hastiarse en el hogar doméstico con las frivolidades femeninas, que ayude a la mujer, que la inspire y que la proteja para que de oruga se transforme en bella mariposa. ${ }^{87}$

Aquí también resulta importante el planteamiento expresado acerca de la necesidad de establecer nuevas formas de relación entre las mujeres, basadas en un nuevo sentido que podemos asociar con el de una fraternidad solidaria. Ello es importante si recordamos que la moral que domina condenaba la formación de grupos de amistad o de actividad conjunta entre mujeres si no estaban mediados por la actividad de las congregaciones piadosas o los actos de filantropía social. Al afirmar, por ejemplo, que las mujeres "perfectamente conocen los sufri-

${ }^{87}$ Ibid. 
mientos de su sexo" parece apuntarse un primer reconocimiento de una condición femenina particular ante la cual se afirma que las mujeres "deberían amarse y sostenerse mutuamente" cuando, por el contrario, se reconoce que la competencia y los celos llegan a ser violentos entre ellas hasta el punto de que "pocas señoras mayores perdonan a la infeliz obrera o a la criada el que sean jóvenes y bonitas". 88

Así pues, al considerar en su justa medida esas reivindicaciones, podemos vislumbrar la importancia crucial de tales posiciones que buscan situar la experiencia amorosa en términos más cercanos a la experiencia concreta, y frente a la permanente discursividad de una expectativa amorosa no siempre corroborada por la realidad. Asimismo, podemos observar cómo en forma paralela se conforma otro tipo de ideal amoroso en el cual se estipula, por ejemplo, que "el amor crece a medida que el hombre y la mujer se conocen, que han vivido y gozado mucho juntos". ${ }^{89}$

En segundo lugar, vemos un discurso que no sólo cuestiona severamente la conducta definida como ideal en las relaciones amorosas, sino que, más aún, muestra escepticismo ante esa visión, identificándola más bien con una falsa posibilidad (al menos en la forma imperante) de alcanzar, junto con el hombre, a una real igualdad de oportunidades para experimentar el amor.

${ }^{88}$ J. Michelet, "Ultimo amor, amistades de las mujeres", Violetas del Anáhuac, año II, t. I, núm. 24, 1889.

${ }^{89} \mathrm{Ibid}$., "La esposa quiere asociarse y depen. der", ibid., núm. 22, 1889.
¿Es realmente una virtud corresponder a las vejaciones, al mal trato y a las humillaciones de todo género, con el amor más abnegado, con el sacrificio de la salud, de la dignidad, de la reputación y tal vez con el de la vida? Esas pobres mártires que hacen una religión del amor a su verdugo y que no comprenden el deber sino en el sacrificio, ¿obrarán realmente inspiradas en los sólidos principios de una educación moral bastante elevada, o quizá obedecen a una ley ineludible y fatal y en tal virtud obran inconscientemente?90

La respuesta a tan contundente cuestionamiento es asimismo un replanteamiento crucial de los conceptos sobre los que se establece el ideal amoroso tradicional:

En este punto los místicos y los enamorados se confunden. En unos y otros la humildad llega al extremo de menospreciarse para enaltecer al objeto amado, pero yo creo que el amor no debe sufrir esas humillaciones del alma, que ese lujo de menosprecio no debe existir y que la estimación mutua ha de establecer el nivel y la igualdad; pues si el amador está tan abajo del ser amado, o al contrario, no puede establecerse mezcla ni correspondencia alguna, porque no puede armonizarse el todo con la nada. ${ }^{91}$

Unida a la certeza con que las autoras señalan su desaprobación ante un orden establecido sobre los cimientos de grandes desventajas para ellas, en el que "antes han falseado el amor los

90 Mateana Murguía, "Emilia", ibtd., núm. $14,1889$.

91 Ibid. 
hombres que las mujeres, dígalo si no la historia de la poligamia", y donde "los escritores atolondrados y los murmuradores sin gracia buscan en el arsenal del amor armas con qué combatir a la mujer", se asoma la presencia de un enojo antiguo contra estos "cobardes" escritores a quienes "más valía educar el corazón de la mujer que burlarse de sus extravíos", no sólo porque se piensa que "en las contiendas del amor el hombre es juez y parte", sino por la confirmación de "icuán cierto es que las mujeres han compuesto el gran poema del amor, y los hombres lo comentan sin llegar a comprenderlo!"92

En este reclamo se confronta también la incompatibilidad entre el ideal amoroso para el que las mujeres han sido educadas y la realidad de la práctica amorosa. Dicha posición, que se muestra poco crédula de los favores y beneplácitos espirituales con que la moral porfiriana asocia al amor, adquiere un mayor número de adeptas a la publicación durante 1889 a través de textos como el siguiente:

¿Creíste en el amor?... espectro vano. que con ropaje de ángel aparece. Flor que galana en el jardín se mece, ocultando en sus hojas el gusano. Fuente que cubre mísero pantano, Dios que su culto al corazón ofrece. Y en medio a su fulgor se desvanece. Dejando luto en el altar profano... ¿YY extrañas aún que el néctar que vertiera, de su engañosa copa transparente. En veneno letal se convirtiera?... ¡Pobre mujer! en tu idealista frente la verdad sustituye a la qui-

92 "Pensamientos célebres, Catalina Severo", ibid., núm. 17, 1889. mera: la fría verdad al corazón ardiente. ${ }^{93}$

No existe, sin embargo, una resolución diferente ante dicha situación, más bien hay un retorno al concepto, antes mencionado, del amor como un sentimiento de naturaleza contradictoria y, en algunos casos, como una irresolución total que no conduce sino a una suerte de amor infructuoso o destinado al sufrimiento. Creo, sin embargo, que estas expresiones tienen una valiosa significación en el pensamiento de mujeres que, como las que aquí hablan, no se explican a sí mismas únicamente al lado de su amado creador (¿o su creado?).

\section{La evidencia de lo prohibido}

Un hecho que llama sobremanera la atención en la mayoría de los textos revisados es la permanente intención de enseñar o predicar un comportamiento específico. Este sentido didáctico del discurso se expresa, por un lado, a través de un recurso que ya hemos observado antes: el señalamiento detallado de las conductas normadas aprobatoriamente por la moral social imperante; por otro, en la elaboración de anécdotas que ejemplifican las infortunadas consecuencias a que conducen las prácticas no apegadas a dicha normatividad. Lógica del todo coherente con la concepción católica predominante sobre el "castigo" como

${ }^{93}$ Laureana Wright de Kleinhans, "A...", 1 bid., núm. 17, 1889. 
suceso inevitable ante la desobediencia del orden natural o divino.

Así, todo desapego a la función espiritual del amor es considerado un acto acreedor de la condena social y la reprimenda divina. Ahora bien, tal desviación a la norma representa sobre todo la supremacía de la pasión, en otras palabras: la aceptación de una experiencia amorosa que no excluye a los sentidos ni al cuerpo. Es decir -aunque por supuesto nunca aparece en tales términos-, el deseo carnal y la práctica sexual.

Hecho pedazos ya por las pasiones mi pobre corazón te vengo a dar; si ha de ser venturoso mi destino, ven conmigo mujer, ven a gozar. ${ }^{94}$

Como en el poema anterior, la novela anónima Pasión y extravío, ${ }^{95}$ que aparece por capítulos en varios números de la revista, ejemplifica esta didáctica que, una vez más, da cuenta de un concepto binario del mundo: una joven huye de su casa con un muchacho rico y de costumbres "relajadas"; éste le promete su amor y la oculta en una casa de provincia pero nunca cumple su promesa de casarse con ella. $\mathrm{Pa}$ sado un tiempo, la joven pretende contraer matrimonio con un hombre de la comarca, pero es sorprendida por el sujeto de su primer amor y asesinada por él, quien en un arrebato de celos se quita además la vida. Al final, la autora (o el autor) señala claramente la moraleja:

${ }^{94}$ E., "A ti", ibid., núm. 24, 1889.

${ }^{95}$ Anónimo, Pasión y extravío, ibid, año 1 , t. I, núm. 7, 1888.
Ved en la presente historia los desastrosos efectos de la ligereza juvenil y los peligros a que estáis expuestas; desconfiad siempre del amor, y preferid al sentirlo, que sea bajo la égida de vuestros padres, pues ellos solamente sabrán conduciros por el camino del honor yla virtud. ${ }^{96}$

En historias como ésta, que hacen hincapié en la infelicidad y los desgraciados destinos de sus protagonistas, suelen asociarse dichas conductas irregulares con la ausencia de elementos como la fe religiosa y el equilibrio mental. Así, toda conducta femenina alejada del destino natural asignado por el orden divino se reconoce como una afrenta religiosa y coloca a las mujeres en una difícil situación pública de enjuiciamiento moral y desprecio social. Sobre la significación de esta asociación entre la infracción a la norma y la locura femenina, cabe mencionar que durante el porfiriato el número de suicidios femeninos aumentó considerablemente, y las principales causas a que se atribuyó fueron las enfermedades y la "locura de amor". ${ }^{97}$

Mirad; ¿no veis una mujer que llora desgarrando su espléndido atavío? En sus ojos ¿no leeis el desvario y en su pálida frente la aflicción? Amor, dice: palabra emponzoñada que acibara y agosta la existencia, es la virtud, locura que en esencia

${ }^{96}$ Ibid.

97 "Hacia 1900 el suicidio era considerado endémico. Al principio sólo lo practicaban estudiantes positivistas, y después aun las mujeres de cierta clase social. No faltó quien considera. ra que se trataba de una estúpida manía romántica". González, Historia, 1970, pp. 430-436. 
al hombre le provoca amargo reír. ¡Pobre loca! ¿Oísteis? ¿Qué blasfemia! Duda y de todo histérica maldice ¡Y no tiene ilusión que divinice su existencia en el mundo con amor! ¡Dudas de todo! El mundo te da pena y de luto tan sólo te rodeas.

¿Has olvidado a Dios?, qué, ¿no deseas a otros mundos llegar, pobre mujer? ${ }^{98}$

La referencia casi exclusiva a las "infractoras" femeninas no significa la inexistencia de un señalamiento social contra la conducta pasional masculina, pero como hemos mencionado, ésta era una característica considerada instintiva o propia de la naturaleza del hombre, lo cual suponía en éste mucho mayor propensión a practicarla. Por ello el desapego masculino respecto de las normas nunca se recriminaba con el mismo rigor que a una mujer. De hecho, el código civil de 1884 establece un parámetro jurídico por completo desigual en cuanto al tratamiento del adulterio femenino o masculino; el primero es siempre causa de divorcio, el segundo sólo cuando es "público o escandaloso o se agrede a la esposa legítima". 99 Bajo el mismo criterio se defiende la primacía de los espacios privados o domésticos como

98 Catalina Zapata de Puig, "La loca", Violetas del Anáhuac, año 1, t. I, núm. 47, 1888.

99 "El adulterio es una falta esencialmente femenina, que no sólo rompe con su natural es. tado de dependencia hacia su marido al serle infiel, sino que amenaza la institución del matrimonio al introducir la duda sobre la legitimidad de los hijos, afectando consecuentemente los bienes y patrimonios familiares...el adulterio del hombre sólo es visto como una simple infidelidad que puede dañar el amor de la esposa, pero no su honra". García, "Divorcio", 1992. la residencia ideal para toda expresión afectiva y nunca en los públicos, considerados más facilmente propensos a la ausencia de normatividad; el ámbito público es incluso innecesario, según se dice, porque cuando una mujer

tiene sólidos principios de virtud y religión, y cuando ama de veras al hombre a quien ha unido su destino, encierra el mundo en sus hijos y su casa y no deja errar su imaginación en peligrosos desvaríos. ${ }^{100}$

Conducta por la cual, además, se impone la prudencia de no exponerse a emociones y sentimientos desafortunados, como se narra en el caso de un hombre enamorado de una actriz:

Viéndola libre su amor se convirtió en pasión, acompañada de todos los sufrimientos que lastiman el corazón de un hombre delicado que se enamora de una artista: los celos, la duda, los deseos; la tortura de ver a la mujer amada sobre la escena, expuesta a las miradas de otros hombres, y la angustia de pensar que pertenece al público y no a él. ${ }^{101}$

En contrapartida, sin embargo existe otro discurso que, aunque minoritario, da cuenta de conductas amorosas en las que se expresan estados de ánimo y sensaciones no permitidas o de indole pasional.

Te mando mis suspiros y mis besos y mi alma enamorada vuela a ti.

${ }^{100}$ Ma. del PilarS., "Consejos de mujer (a una casada)", Violetas del Anáhuac, año n, t. II, núm. 5, 1889.

101 "Sobre la vida de Sofia Arigoni, actriz", Las Hijas del Anáhuac, año I, t. I, núm. 7, 1888. 
¿No la sientes que llega y te acaricia? ¿No sientes que se acerca y que te besa...?

¿No sientes que en tu boca deja impresa la huella de los besos de mi amor? ${ }^{102}$

La mención del apasionamiento como una expresión más de la vivencia amorosa, así como la representación del placer y goce experimentados en ella, aparecen como una lente del todo diferente a la que la moral predominante designa para mirar las conductas amorosas. La introducción de un discurso pasional permisivo, resulta a todas luces de importancia si consideramos la "satanización" de la pasión en la estricta moral religiosa del periodo.

Y en esas horas de supremo encanto no piensas en mi amor con más anhelo y de la ausencia desgarrando el velo ¿no me ves a tu lado en tu pasión? En las vigilias de mis largas noches te siento junto a mí tierno y amante $y$ te estrecho en mis brazos delirante, trémula de ventura y de placer; y siento que tus besos en mi boca dejan miel y dulcísima ambrosía y aún a la aurora del naciente día en mis amantes brazos te creo ver. Y oigo tu voz apasionada y tierna que con su dulce acento me enloquece y a cada instante mi pasión acrece y olvido entre tus brazos mi dolor... Por eso amo la noche y sus misterios para soñar contigo y con las bellas sonrientes ilusiones de mi amor. ${ }^{103}$

Es necesario resaltar que la tónica general de este discurso amoroso es la

102 Ma. de la Luz Murguia, "En tu ausencia", Violetas del Anáhuac, año I, t. I, núm. 23, 1888. 103 Ibid. construcción de ambientes que refieren a sensaciones y casi nunca a expresiones concretas sobre el deseo corpóreo de la persona-objeto de amor. Asimismo, su estructura reúne una curiosa mezcla de elementos idílicos con otros prometedores de goces y bienestar terrenales, expresados por cierto a través de la poesía, que se presenta como la forma preferida para la expresión de lo afectivo. Asimismo, resulta significativo que sea el discurso elaborado bajo firmas masculinas el que contemple abiertamente al cuerpo como un elemento fundamental e inseparable de la relación amorosa entre un hombre y una mujer.

Tu ninfa admiro pudorosa y casta, pero no envidio tu celeste ensueño, a mí tanto idealismo no me basta; yo quiero ser de mi adorada el dueño. Mi amor es luz, deleite y alegría, tu amor es sombra vagorosa y triste, yo palpo y gozo la ventura mía, tú forjas un amor que aquí no existe....yo quiero la mujer viva y ardiente, y mal comprendo la emoción secreta de una mirada lánguida y doliente. Soñar y no vivir no me contenta, a tí te cuadran soledad silencio, a mí sólo la vida y la tormenta. Tu mística quimera es amor vano, sueños no son amor, son sus reflejos, ¿puede ser en verdad amor humano amar como las plantas desde lejos? ${ }^{104}$

No así para el caso de las autoras que, como dije, suelen entremezclar la referencia de emociones e imágenes corporales exaltadas, con las expresiones tradicionales de lo amoroso,

104 "Amor idealista-Amor naturalista", ibid., año II, t. II, núm. 14, 1889. 
como la ternura y otras. A pesar de ello, no me parece aventurado brindar una enorme importancia al registro de estos discursos que rompen con la moral imperante y nos muestran otros rostros del sentir amoroso femenino, en tanto dicha experiencia no se presenta ya determinada únicamente por la aceptación de un papel social estructurado sobre la premisa esencialista de la condición biológica, ni por la vivencia afectiva relacionada con el sufrimiento, la abnegación o la infelicidad como destinos inevitables en la práctica del amor fuera de los cánones establecidos socialmente. En otras palabras, nos brinda una imagen femenina construida más allá de los límites establecidos por su tan mencionada como supuesta naturaleza amorosa y bajo la certeza, significativamente, de su temporal residencia en el mundo. "¿El amor? ¡Ah!, en la tierra no existe otra cosa. Amemos hoy, ya que mañana tal vez habremos dejado de existir". 105

\section{CONSIDERACIONES FINALES}

Termina este primer acercamiento a las ideas sobre el amor expresadas en la revista Violetas del Anáhuac; pese a que no hemos pretendido realizar un análisis exhaustivo, es necesario apuntar algunas observaciones en relación con el discurso amoroso aquí abordado.

El ideal amoroso predominante en Violetas del Anáhuac nos ofrece un

$105 \mathrm{~J}$. Michelet, "Último amor, amistades de las mujeres", ibid., núm. 24, 1889. concepto del amor elaborado a partir de una supuesta diferencia moral y espiritual entre el hombre y la mujer, derivada a su vez, de la diferencia biológica o fisiológica existente entre ambos. Dicho supuesto se inscribe como resultado de una realidad social ordenada a partir de un principio dico. tómico o binomial amplio. Más explícitamente, la naturaleza humana obedece aquí a una serie de oposiciones que la constituyen esencialmente y que se expresan en pares como: hombre/ mujer, pasión/amor, cuerpo/espíritu, real/ideal, moral/amoral, natural/pervertido. En esta expresión del mundo, el concepto de lo "natural" resulta sustancial como determinante del orden establecido en las relaciones sociales, así como el uso de otros conceptos que se colocan como valores correspondientes a dicha naturaleza: normal, bueno, correcto, decente, etc. El establecimiento de tales juicios de valor adquiere una importancia singular en el contexto de la filosofia positivista, que vemos como una influencia determinante en el pensamiento político, filosófico, científico y social del periodo porfirista, ya que esta corriente de pensamiento establece, a su vez, una "función natural" específica a la expresión humana de lo afectivo (estatuto en el que se incluye el amor como una manifestación de los sentimientos) y considera a la mujer el sujeto que, por su posición natural biológica en la condición humana, debe cumplir esta función para contribuir a una existencia social armónica y a la reproducción de la especie. Ello explica al amor como un elemento que contiene la esencia de la espiritualidad 
humana, que ha sido otorgada por el dios cristiano para brindarle la oportunidad de establecer en la tierra el orden prescrito por él.

La posibilidad de cumplir ese mandato divino sustenta, a su vez, el segundo gran concepto identificado de manera general sobre el amor. Aquí, lo amoroso se presenta como un hecho que muestra la permanente lucha de los seres humanos por asumir su mandato espiritual -es decir, vivir bajo el principio de la armonía y estabilidad que supone el amor a Dios y los preceptos por él establecidos- o la tendencia humana a alejarse de dicha consigna. Esta expresión del amor como un sentimiento de naturaleza contradictoria contiene en sí misma la idea del amor como esencia espiritual, y ambas -expresión e idea del amoradquieren una connotación concreta al formar parte de un discurso que dicta conductas específicas acerca de cómo debe ser precisamente expresado y vivido el amor. En otras palabras, se establece un ideal sobre el comportamiento amoroso "deseable" en virtud de su consideración como natural, espiritual, positivo y, bajo el espíritu religioso imperante en la época, católico.

El análisis de este discurso sobre el amor nos muestra, por un lado, una correspondencia lineal entre la concepción general hasta aquí descrita y las ideas imperantes sobre el papel social de las mujeres durante nuestro periodo de estudio. Las mujeres, decimos, eran consideradas entonces depositarias de un poder espiritual expresado a través del sentimiento, la moral y la educación; y a partir de ello se les atribuían acciones y espacios pertenecientes al "mundo privado" de la estructura social: matrimonio, familia, maternidad y educación de los hijos - todo ello dentro de preceptos católicos que normaban dichas experiencias. Por otro lado, hallamos aquí un discurso que persiste en oponerse a las nuevas ideas que poco a poco cuestionan la condición social de las mujeres en ese momento, y que intenta usar el discurso moral como medio de control frente a los impactos y cambios producidos en el país por la creciente inserción de las mujeres en diversas actividades productivas, políticas, educativas, científicas y literarias.

Si atendiéramos sólo a ese ambiente generalizado de oposición al cambio, estaríamos de acuerdo en que, a pesar de todo, el ideal dominante de lo amoroso convive sin gran esfuerzo con las transformaciones económicas y sociales ocurridas en el México porfirista de finales del siglo XIX. Sin embargo, no debemos pasar por alto dos elementos que confirman, al parecer, que dicho ideal amoroso comienza a perder paulatinamente su vigencia dominante.

Por un lado, resulta significativa la insistencia en un discurso que pretende, en primer lugar, establecer cuál debe ser la conducta moral de la mujer -y en menor grado también del hombre- $y$, en segundo lugar, prevenir acerca de los peligros que supone una actuación femenina fuera de la norma, pero no sólo en términos de la reprobación espiritual para la mujer como individuo adscrito a una fe religiosa, sino también por las consecuencias desestabilizadoras que ello significa- 
ría para la sociedad. Por otro, es determinante la presencia de discursos que, aunque minoritarios, critican e incluso niegan el destino social asignado a las mujeres en función de la supuesta esencia amorosa que se les atribuye.

Ahora bien, es cierto que la mayor parte de esta literatura no trastoca el esencialismo determinista que sustenta el ideal amoroso imperante y el es. tablecimiento de papeles sociales para los géneros, pero su presencia da cuenta de nuevos elementos -entiéndase no tradicionales- que se introducen con el intento de anotar significados diferentes para el ser de las mujeres y de una experiencia amorosa que enuncian como deseable, así como de otra que en contadas pero extremas ocasiones manifiestan como irreal, innecesaria, o bien, experimentada de forma diferente a la prescrita por la moral social. Si consideramos también la presencia de testimonios que muestran conductas no inscritas en el estereotipo tradicional, como las expresadas en los relatos de viajeros extranjeros que describen prácticas equivalentes a formalismos como el cortejo o el matrimonio, me refiero, por ejemplo, a la costumbre del "rapto" y la huida de las muchachas en distintos sectores populares, ${ }^{106}$ así como al registro

106 "En cuanto a las mujeres de este grupo (sirvientas) son por lo general mestizas [...] Su cerebro es una mezcla estrambótica de las ideas que espontáneamente produce su cerebro, que se halla en un estado psicológico de creencias en brujerias y hechizos, y de las que oyen a sus amos. Son de moral relajadísima y tienen amores simultáneos o sucesivos con los mozos de la casa. Ellas son las que inician a los niños de la familia en los secretos del amor; forman la prime- de mujeres que "alegan en casas, calles, plazas y tribunales", ${ }^{107}$ entre otros, podremos pensar entonces que la insistencia de un discurso moral en apariencia muy interesado por determinar un estereotipo único del deber ser femenino puede explicarse, en buena medida, como un intento por mediar con una realidad que, con seguridad, se presenta en forma muy diferente a como se pretende establecer, sobre todo en los grupos sociales no privilegiados. 108

En esta perspectiva, es importante señalar una contradicción central que atraviesa el discurso del "deber ser" amoroso dirigido a las mujeres. Mientras que, en términos de la filosofía positivista, el estadio ideal (positivo) para la totalidad del conjunto social es el signado por la práctica de lo "científico", a las mujeres se les explica y asig. na un deber social a partir de una concepción biologicista. En otras palabras, parece que lo científico como positivo sólo concierne a uno de los sexos, ya que para las mujeres lo positivo designa más bien lo natural-biológico.

ra novela de los estudiantes, y son las que persigue con más tenacidad la policía de sanidad [...], están acostumbradas a verse disputar a puñaladas, para entregarse al vencedor $[. .$.$] y a$ veces al vencido también". Guerrero, Génesis del crimen en México, citado por Rocha, Álbum, pp.100-101.

107 Tuñón, Álbum, 1991, p. 13.

108 "Las fuentes primarias nos permiten percatarnos de la diferencia entre hecho y derecho, entre idea y realidad, nos permite ver las relaciones de ida y vuelta entre ambas, la dificultad o imposibilidad para conciliarlas a veces, pero en otras la fluidez con que se combinan, $y$ el peso de cada una de ellas en la otra". Ibid., $\mathrm{p}$. 13. 
Pero no es aquí donde reside lo significativo de dicha contradicción, sino en lo que puede evidenciarnos el incansable esfuerzo por enfatizar las fronteras y formas de esa naturalidad cuando, en términos del discurso positivista que hemos planteado, lo que es natural no necesita de enseñanza alguna, en virtud de su supuesta representatividad de la esencia humana en el proceso de evolución de las socieda des. Entonces, ¿cómo o por qué pretender realmente "enseñar" lo que es natural? Para responder a dicha cuestión en el periodo de 1821 a 1880 se ha dado la siguiente respuesta:

Una primera lectura de cierto material nos hace sentir absurdo el discurso moral, tan excesivo en cuanto a la rigidez sexual y la cortesía, tan cursi en la caracterización del pudor, la virginidad, la discreción. Sólo cuando accedemos a los mundos reales estos acartonamientos pueden explicarse: se trataba de conjurar los excesos de la vida con la medicina de la decencia, y al fallar ésta se aumentaba la dosis: como los médicos que ante el debilitamiento producido por una anemia recetaban jotra sangria!109

Si es así también para nuestro periodo de estudio - y considerando que un elemento común en la prensa de fines del siglo XIX era el poder simbólico otorgado a la palabra escrita como un medio transmisor que responde a la idea rectora de la política educativa porfirista (lograr que el pueblo se ilustre)-, la presencia de revistas femeninas concebidas por y para mujeres

109 Ibid. resulta una expresión fundamental que da cuenta del interés de las mujeres de aquel tiempo por manifestar su opinión acerca del papel que en la colectividad social se les asignaba, por establecer diversos grados de cuestionamiento a las prohibiciones establecidas para su acceso a las distintas áreas de la cultura, la política, la educación, el trabajo remunerado, etc. Quizá, por último, estaba presente la intención de asumir conductas diferentes a las exigidas por la norma social.

Pero lo que puede considerarse el reflejo de una transición sustancial en el tipo de actividades públicas reclamadas por las mujeres no implica, al parecer, la operación de un cambio semejante en los ámbitos de lo privado y de las estructuras mentales que lo significan, al menos respecto a los presupuestos básicos del estereotipo amoroso que hemos definido como predominante. En otras palabras, frente a la reivindicación radical del derecho femenino a insertarse como un sujeto activo dentro del proyecto económico modernizador del momento, no se presenta en contrapartida un cuestionamiento que trastoque con igual fuerza el determinismo esencialista que explica la condición social de las mujeres a partir de su naturaleza biológica, ni la abdicación a las cualidades 0 características positivas asignadas al ser mujer, ni a las tareas consideradas específicas de su sexo. ${ }^{110}$

110 Es importante aclarar que no se dejan de lado las transformaciones que las mujeres de Ias clases privilegiadas estaban realizando en asuntos como la moda o los protocolos de compor- 
¿Cómo explicar esta convivencia, casi indiferenciada, entre lo que pudiéramos llamar la atmósfera tradicional y los vientos de un pensamiento moderno sobre el ser mujer? Ante una problemática tan compleja y determinada por múltiples factores que van más allá de los hechos registrados y transmitidos a partir de las acciones visibles y la conducta consciente de los seres humanos, no puedo evitar preguntarme, por ejemplo, por qué muchas de las ideas que aún hoy en día expresan los estereotipos dominantes de las aspiraciones de las mexicanas en relación con la experiencia amorosa, y el papel asignado en su vida, conservan elementos semejantes al comportamiento ideal femenino que el discurso amoroso aquí estudiado ofrece: tolerancia, pasividad, comprensión, el embellecimiento en función de la mirada masculina, la responsabilidad principal en el cuidado y la educación de los hijos, etc. ${ }^{111}$ No pretendo, por supuesto, extrapolar mis criterios ideológicos, morales y afectivos como mujer del siglo Xx, para observar $\mathrm{y}$ mucho menos buscar la respuesta a la anterior pregunta. Tampoco quiero afirmar que el panorama actual de los asuntos amorosos es idéntico al del porfiriato o al de la primera mitad del presente siglo. Pero me resulta muy probable que la permanencia de rasgos en mayor o menor medida se-

tamiento, pero estos hechos no son indicadores expresos de que se efectuara un cambio seme jante en las relaciones afectivas establecidas con los hombres.

111 En relación con estas similitudes en el discurso amoroso porfiriano y el de revistas femeninas actuales, véase Infante, "Identidad", 1995. mejantes a los reconocidos en el discurso amoroso aquí estudiado, y que, a su vez, no son radicalmente diferentes a algunos de los que durante la colonia se oficializaron como normas morales (aunque significativamente revestidos por el discurso positivista - liberal predominante en el porfiriato de una supuesta cientificidad)-, obedece a una cierta continuidad de los elementos filosóficos y sociales atribuidos al amor y relacionados con un deber ser femenino. Es decir, a un proceso de lentísimo ritmo que los transporta casi salvos entre las vertiginosas transformaciones experimentadas por la totalidad social, durante y después del porfiriato y la revolución mexicana.

En este sentido, me parece oportuno recordar el planteamiento braudeliano acerca de que los procesos históricos son lentos aunque se constituyan de múltiples eventos coyunturales, ya que éstos no imprimen de manera automática las resonancias de su acción. ${ }^{112}$

112 "El historiador tradicional presta atención al tiempo breve de la historia: el de las biografias y de los acontecimientos. Ese tiempo no es, en absoluto, el que interesa a los histortadores economistas o sociales. Las sociedades, las civilizaciones, las economías y las instituciones políticas viven a un ritmo menos precipitado. No llamará la atención de los economistas que nos hran suministrado nuestros métodos en este terreno el que a nuestra vez hablemos de ciclos, de interciclos, de movimientos periódicos, cuya fase va de cinco a diez años, veinte, treinta y hasta cincuenta. Pero aún en este caso se trata, desde nuestro punto de vista, de una historia de ondas cortas. Por debajo de estas ondas, en el campo de los fenómenos de tendencia (la tendencia secular de los economistas) se instala, con imperceptibles inclinaciones, una historia de muy largos periodos, una historia lenta en 
Asimismo, que entre los propios niveles estructurales de lo histórico: económico, político, mental, social, los cambios y/o permanencias operadas en ellos no corresponden siempre a un ritmo único o coincidente, ${ }^{113} \mathrm{don}$ de de manera particular las transformaciones en los sistemas de representación del mundo, "elemento capital de las tensiones y luchas sociales", 114 se inscriben en un complejo campo de "permanencias y resistencias". ${ }^{115}$

Es claro que muchas preguntas quedan pendientes de respuesta. Por ejemplo, ¿a qué responde la continuidad de algunos elementos del discurso amoroso aquí estudiado con el de periodos posteriores? ¿Es el ideal amoroso una construcción del imaginario social en el que se reproducen eficientemente las relaciones de poder? ¿Qué tipo de relación existe entre los ideales amorosos expresados por estas escritoras y la experiencia vivida por ellas y muchas otras mujeres, sobre todo aquellas pertenecientes a sectores de clase distintos?; o bien, ¿a qué responde

deformarse y, por consiguiente, en ponerse de manifiesto a la observación. Es a ella a la que designamos en nuestro imperfecto lenguaje bajo el nombre de historia estructural (structurale), oponiéndose ésta menos a una historia episódica [évenementielle! que a una historia coyuntural [conjoncturale! de ondas relativamente cortas". Braudel, Historia, p. 53.

113 Los procesos históricos son lentos, y en. tre los niveles económicos, políticos, sociales e ideológicos suele faltar la coincidencia. Las cronologías permiten delimitar un periodo para el análisis, pero es claro que las continuidades existen y que los cambios, muchas veces, no respetan sus fronteras". Tuñón et al., Álbum, p. 10.

$114 \mathrm{~J}$. Le Goff, "Mentalidades", p. 72.

115 Ibid. el discurso velado o ausente del cuerpo y la sexualidad de las mujeres en su relación con la experiencia amorosa? Me parece valioso, sin embargo, este primer acercamiento a un aspecto de la experiencia femenina hasta hace muy poco tiempo considerado por la historia, como lo es el mundo afectivo. Creo que en la construcción de una historia en la que las mujeres estén incluidas, es indispensable abordar temas como la subjetividad y la expresión de la afectividad, en la medida en que son una manifestación evidente de la complejidad con que se reúnen e interactúan diversos elementos del entramado psicosocial, cultural y económico de las diferentes sociedades humanas y en las que, como resultado, se conforma siempre un orden específico de relación entre los géneros.

Finalmente, sólo me resta compartir una humilde e importante conclusión a la que he llegado después de este recorrido: la experiencia amorosa es una realidad humana sumamente compleja y los esfuerzos teóricos del investigador social para intentar conocerla son múltiples e interminables. El amor es parte también de esa historia íntima y cotidiana de cada individuo, que es al mismo tiempo "encrucijada de muchas historias y necesario fundamento a partir del cual se construye todo lo demas". ${ }^{116}$ En otras palabras, el análisis de las estructuras afectivas que intervienen crucialmente en la construcción de la experiencia humana, es un universo de estudio que hace evidente la complejidad misma de la historia, un tema para el que las más

${ }^{116}$ Firpo (comp.), Amor, 1984, p. 7. 
elaboradas respuestas pueden resultar inacabadas y relativas, y en las que, sin embargo, siempre debe esperarse ejercer el poder de conocimiento que permite la duda.

\section{BIBLIOGRAFÍA}

-Bazant de Saldaña, Milada, Historia de la educactón durante el porfiriato, Centro de Estudios Históricos/El Colegio de México, México, 1993.

-Braudel, Fernand, La historia y las ciencias sociales, Alianza Editorial Mexicana, 7a. edición, México, 1984 (El Libro de Bolsillo, 139).

-Cano, Gabriela, "Remedio contra la amnesia", Fem, año 12, núm. 64, México.

-Carner, Françoise, "Estereotipos femeninos en el siglo XIX", en Carmen Ramos, (comp.), Presencia y transparencia: la mujer en la historia de México, El Colegio de México, México, 1987.

-Centro de Estudios Históricos sobre el Movimiento Obrero, La mujer y el movimiento obrero mexicano en el siglo XIX. Antología de la prensa obrera, México, 1975.

-El Correo de las Señoras. Semanario escrito expresamente para el bello sexo, Director: José Adrián M. Rico, México, 1884-1887.

-García Peña, Ana Lidia, "El divorcio de Laura Mantecón y Manuel González", en Cuidado con el corazón. Historia de los usos amorosos en el México moderno, INAH, 1996.

-González Navarro Moisés, Historia Moderna de México, vol. vI, El porfiriato. La vida social, Editorial Hermes, México, 1970 .

-Hernández Carballido, Elvira, "Biografia: dos Violetas del Anáhuac", en Diez estampas de mujeres mexicanas, Docu- mentación y Estudios de Mujeres, A.C. (DEMAC), México, 1994.

-Infante Vargas, Lucrecia, "Identidad femenina y conceptos amorosos en revistas para mujeres de fines de siglo XIX y XX en México. ¿Un siglo de distancia?", Congreso Internacional Nuevas Ideas, Viejas Creencias. La Cultura Mexicana hacia el siglo XXI, México, 1995 (en prensa).

- Lagarde, Marcela, Cautiverios de las mujeres: madresposas, monjas, putas, presas y locas, UNAM, México, 1990.

-Lamas, Marta, "Algunas dificultades en el uso de la categoría género", en XIII Coloquio Internacional de Ciencias Antropológicas y Etnológicas, México, agosto 1993. La reelaboración de este trabajo puede encontrarse en la compilación realizada por la autora: El género: la construcctón cultural de la diferencia sexual, Programa Universitario de Estudios de Género/Miguel Angel Porrúa, México, 1996.

-Lau Jaiven, Ana, "Retablo costumbrista: vida cotidiana y mujeres durante la primera mitad del siglo XIX mexicano, según viajeros anglosajones", en Regina Hernández Franyuti (comp.), La ciudad de México en la primera mitad del siglo XIX. II Gobierno y política. Sociedad y cultura, Instituto de Investigaciones Dr. José Ma. Luis Mora, México, 1994.

-Le Goff, Jacques, "Las mentalidades", en Solange Alberro y Serge Gruzinski, Introducción a la historia de las mentalidades, prólogo de Sergio Ortega Noriega, INAH, México, 1979 (Cuadernos de trabajo).

-Monges Nicolau, Graciela, "El género biográfico en Mujeresnotables mexicanas de Laureana Wright de Kleinhans" , en Ana Rosa Domenella et al., Las voces olvidadas. Antologíacrítica de narradoras mexicanas nacidas en el siglo XIX, El Colegio de México, México, 1991.

-Parcero, María de la Luz, Condiciones de la mujer en México durante el siglo XIX, INAH, México, 1992.

-Pasternac, Nora, "El periodismo feme- 
nino en el siglo xix: Violetas del Anáhuac", en Ana Rosa Domenella, Las voces olvidadas. Antología crítica de narradoras mexicanas nacidas en el siglo XIX, El Colegio de México, México, 1991.

-Ramos E., Carmen, "La nueva historia, el feminismo y la mujer", en Carmen Ramos (comp.), Género e historia, Instituto Mora/UAM, México, 1992 (Colección Antologías Universitarias). "Señoritas porfirianas: mujer e ideología enel México progresista, 18801910", en Carmen Ramos (comp.), Presencia y transparencia: la mujer en la historia de México, El Colegio de México, México, 1987.

-Rocha, Martha Eva, El âlbum de la mujer. Antología ilustrada de lasmexicanas. IV. El porfiriato y la revolución, INAH/ Conaculta, México, 1991.

-Tuñón, Julia, "La construcción del género: mujer itu nombre es amor?", Debate Feminista, año I, vol. 1, 1990, México.
Mujeres en México. Una historia olvidada., Planeta, México, 1987. El álbum de la mujer. Antología ilustrada de las mexicanas. III. El siglo XIX (1821-1880), INAH/Conaculta, México, 1991.

-Vigil, José María, Poetisas mexicanas. Siglos XVI, XVII, XVII $y$ XIX, UNAM, México, 1977, facsimilar.

- Violetas del Anáhuac. Periódico literario redactado por Señoras, Director y administrador Ignacio Pujol, Directora Literaria: Laureana Wright de Kleinhans. 1887-1889. ( Hasta el 22 de enero de 1888 aparece con el nombre de Las hijas del Anáhuac)

-Yamuni, Vera, "El ser y el valer de la mujer comparados con el ser y el valer del hombre", en La naturaleza femenina. Primer coloquio nacional de filosofía, UNAM, México,1985. 


\section{SECUENCIA}

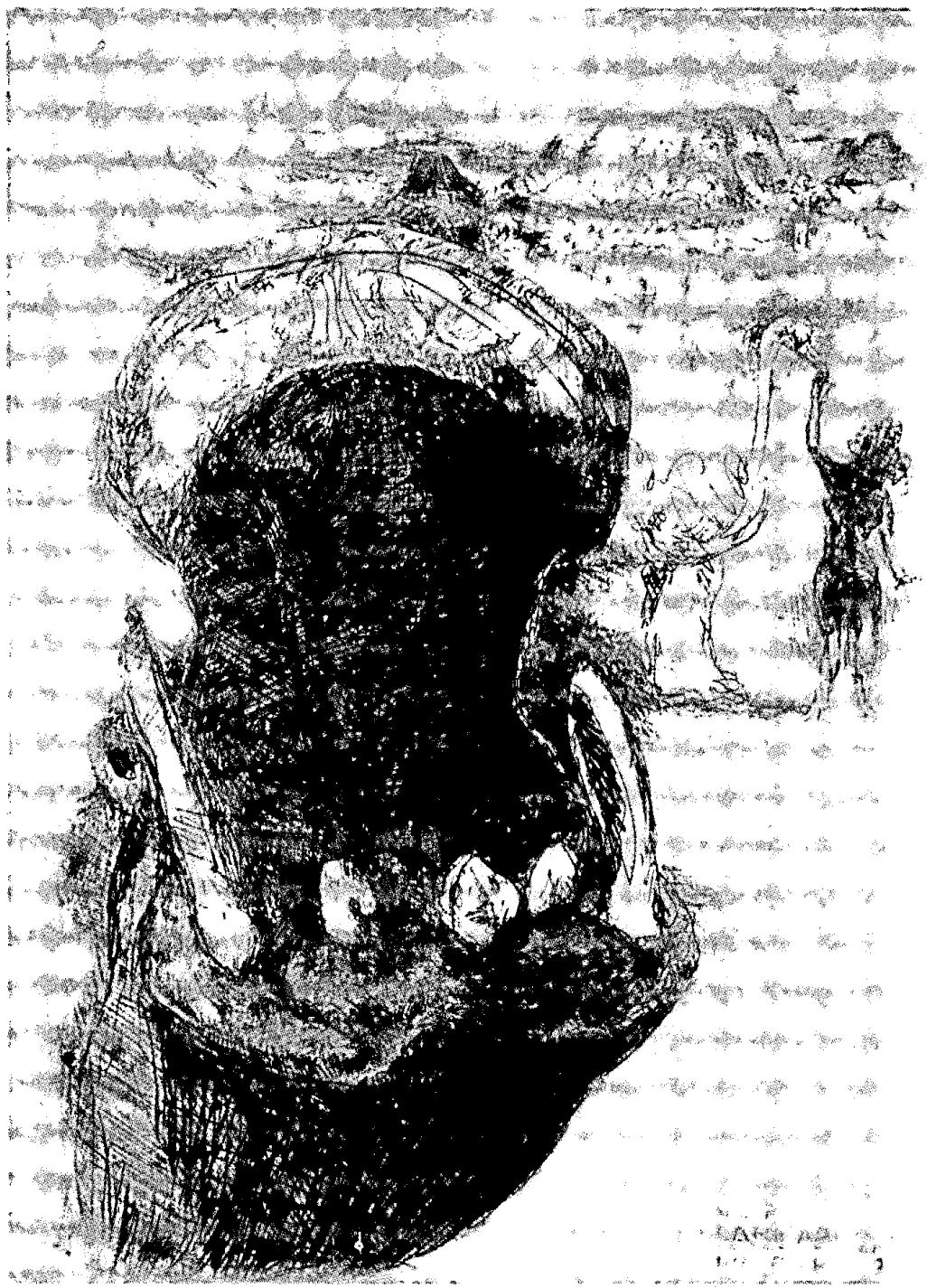

